卑 ᄂ 坤

胃私菑

一は世改

端子界浩

此歷!

開 較，蚛世

陳交の界

ᄂ 化一改

や史大造

5 蒪!

$\varepsilon ?$ 機

思つ督

分人威は

交動 耳

特岕深尼

に理认打

私學 殿

は一ま早

心のし鐘

の上足の

眼 加世 如

者 5 界

大標人世

き題界

くにに

見中湧響

開 う怘

的し 白

$\tau \backslash ぬ b$

世古つ

界〈〉端

改し あ

造てるな

に新。保

至占こ寻

るしの 到

歷 $心$ 光承

史 間离し

心題 3 た

理に好光

對時

闈 $し$ 期 0

明矂に澵

乙 際乾
の)現飞視中

問象ですに

題をあるは

上攻 b人人

克究ま名格心

御方吉省理

覽た高餘等研

に心吾餘掕研

るではに未

があ一輕熟第

小方視等卆 心まにす本唬

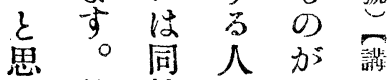

ひ終情々 大

まにをと部語

专本析の分

邦 ᄂ 三 市

終出、種了

造

至

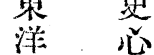

大 理

Us

學

鄁

師

F

的

り

濯

㙐

寈

If.

4 章法名多突

しにの之

てょでに

はりあは

小興 乌或 箱

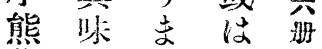

學古し一。

土乌方三

の 價 注 に公

ᄀ值 意 餘

心 す 守

靈るる゙に

現こき神

像の气秘 


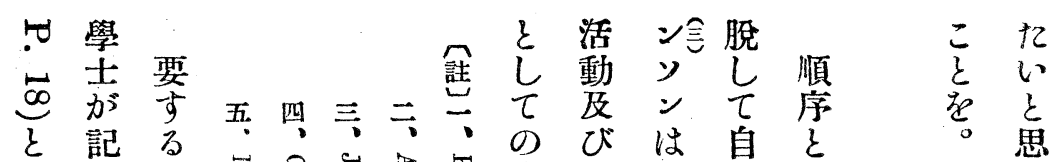

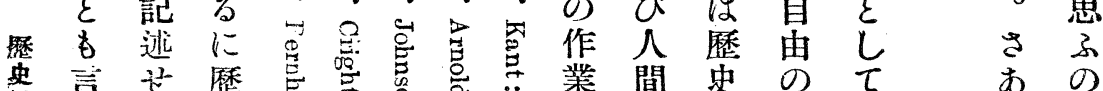

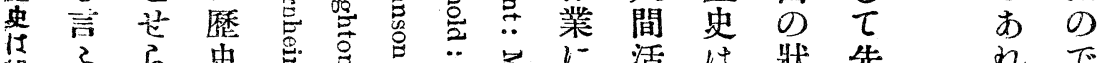

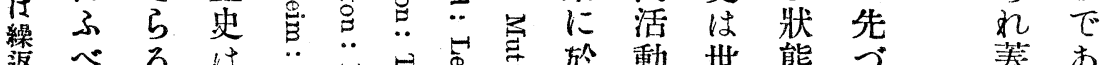

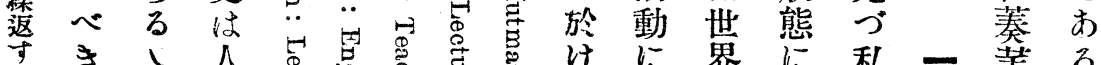

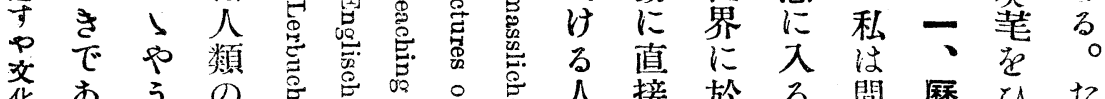

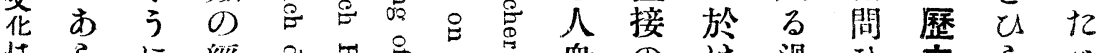

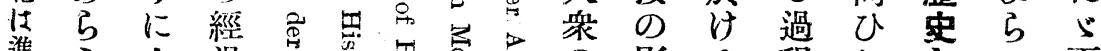

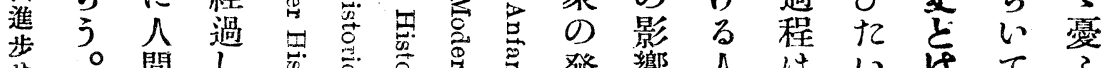

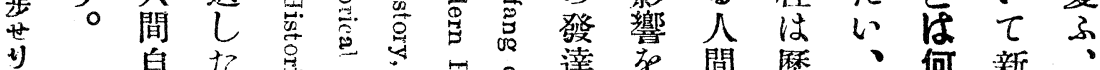

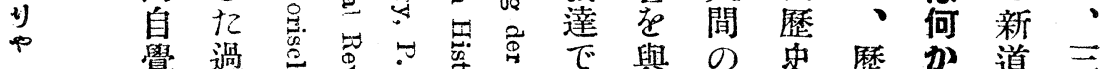

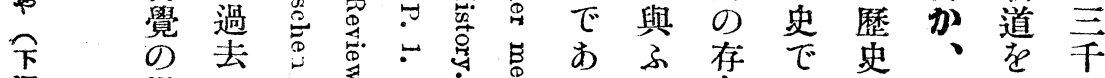
㴗過 の

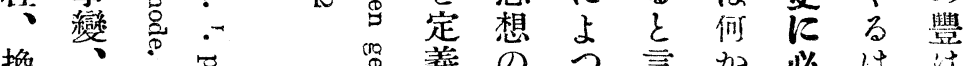
換人要事義のつ言加必沙 言人粠

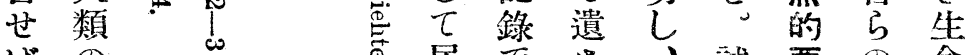
ばの 居でさ、拭要の命 如 表 る市れアミる素任の

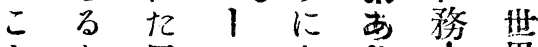
$\varepsilon \varepsilon$ 思, 安 $\mathrm{y} !$

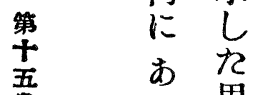
を記想ル献 見し感ドを学史

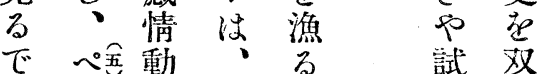
荛へ想 き 情 か 意 の 志

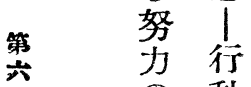

然 動

跡 $の$

こ總

るで

自 紀

我 平 論 文

あ皮歷人眙 らン。史々 $々$ \% う八刀四蛙桹中

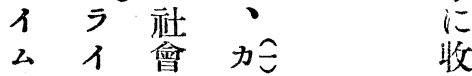
はンのン め

歷卜傳卜 史ン記 は をはで自 社 歷市 然

會史る の

的は。㷋

存人ジ見

在間 $\exists$ を

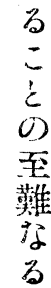




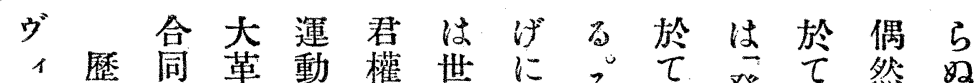

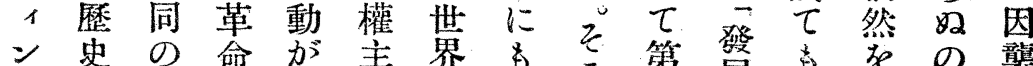

デ家國を起義政第云十第正離だ的

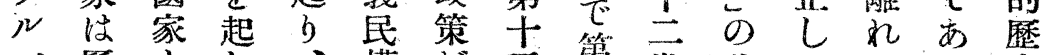

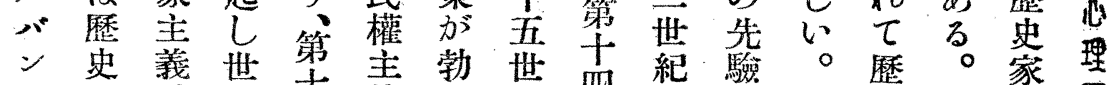

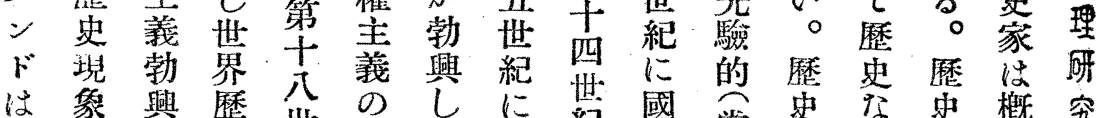

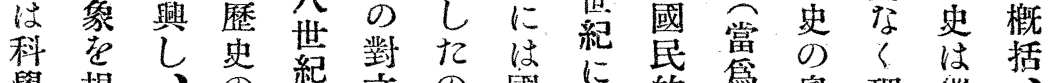

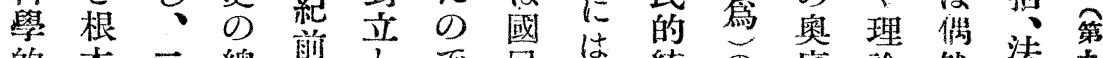

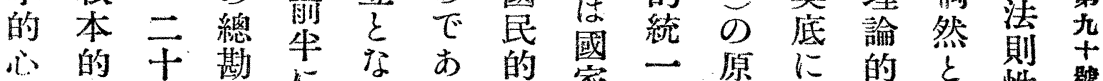

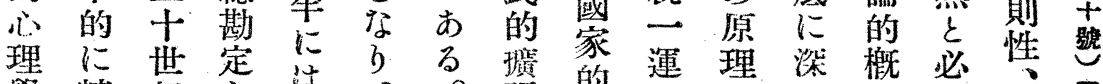

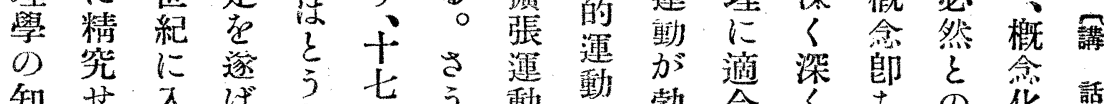

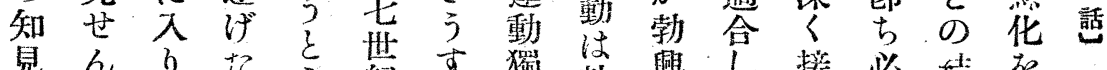

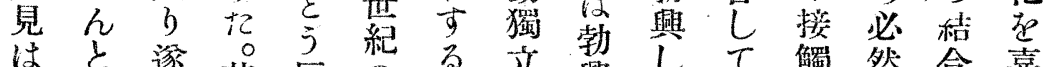

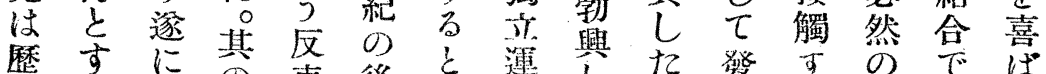

歴 9 束後穴連した發すののでば

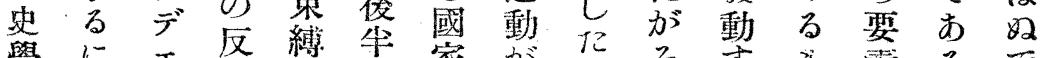

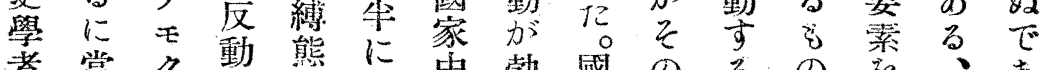

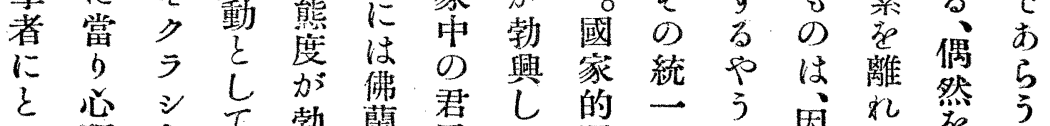

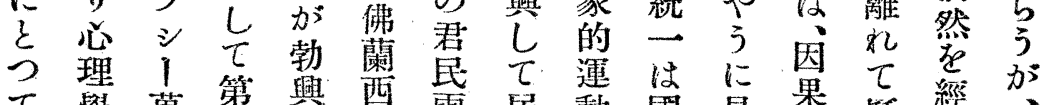

$\tau$ 學萬第興西兩居動國見果歴經少

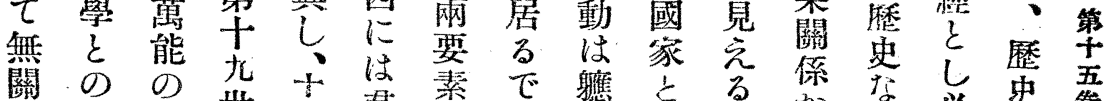

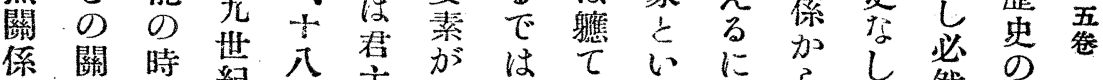

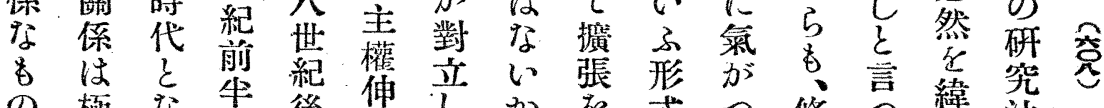

の極な生後傦し加表式つ條言緯法

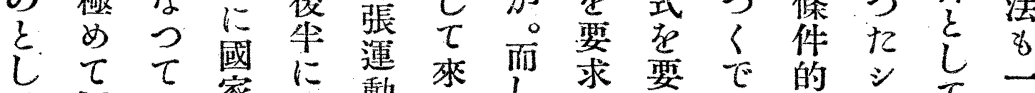

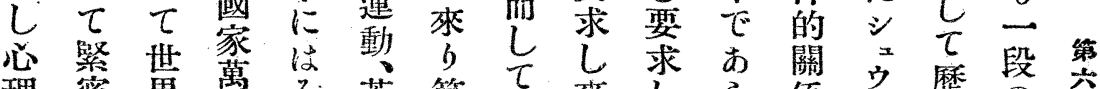
理䅎 界 萬

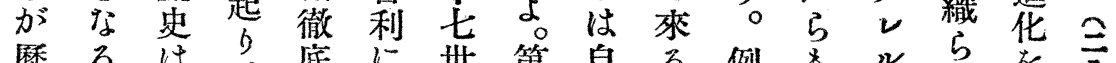

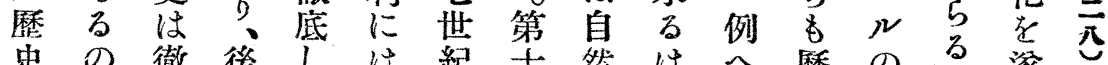
史の徹後し 紀十然は人歷の方逐 學で底牛て民前六で自ば史說動げ のあしに佛權牛世然西の桜機 基るた君蘭伸に紀るで洋發今鼿ば 礎。尼西張はに。出に達にちな 
て方こ人け質以生てめ望應歷問と

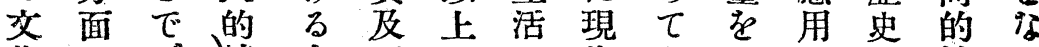
化はヴ情人びにの代發開心忍性る 魔名遠

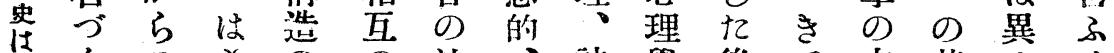
繰く 22 心 渠了將理聯關則諭人怕であ面礎、歷

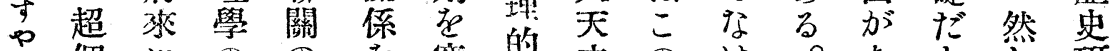

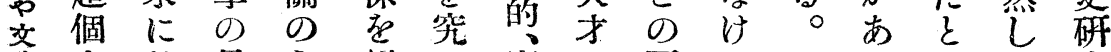
化人於最引規子實の要れ—るせ究 淮的て る 隻目民重に和に的理になので加の 的族要理る專理: 或引史古名て惯 や組心な解に忍解社る刚學る有め際 織理る枯过し會程と者。力に 令で學問るでて進忍度言岁さな基熊

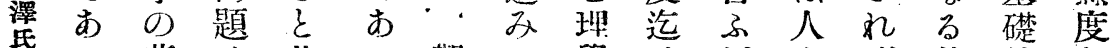
芯方背性共つ觀つ學はが心ば基的を

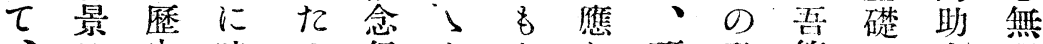
、に史時こ信市夫し研發等の力視

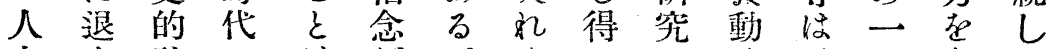

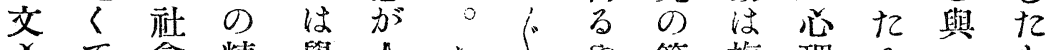
心で會精學人心(や管複理る公る

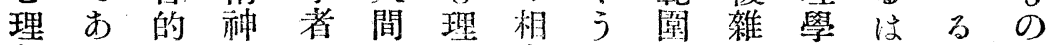
學引留的の行學當にがでに否々で

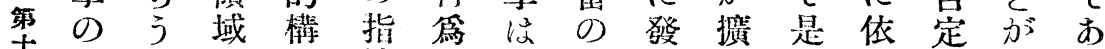

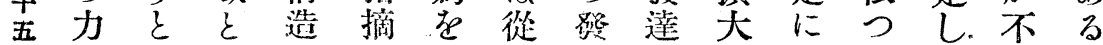

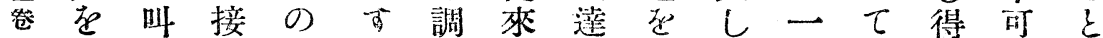

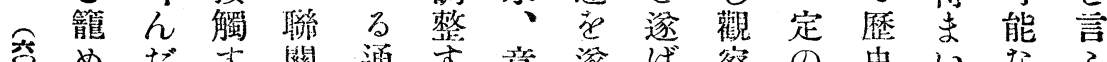

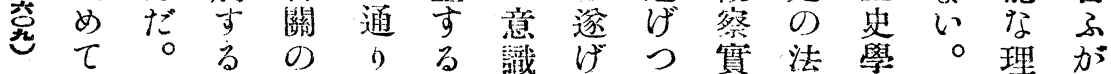

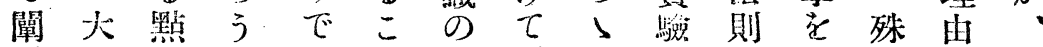
明仕に古市分居 第せ掛あにる、類古るれ見當心な程

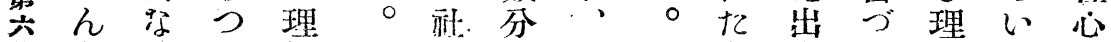
册 $飞$ 個 $\tau$ 解心會析且歷事可以學。理 寸人、世理制及弓串實二深に又學

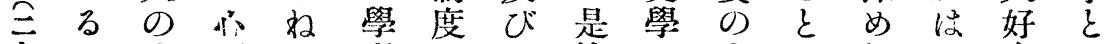
旮姿理 保者及其等の大組县矣歷 こは學なは灿の要い忍織體、史 万: 0 万體社要直壬に理し的心學 のく實双驗會奖觀る增學、忍理と る。驗。存に有理 日加の新理學は ○め的飞個於性解常し極屡學は學 
をなずるにし學る十パ人めめ洞で 比ざ、る於て 的の分ウは察

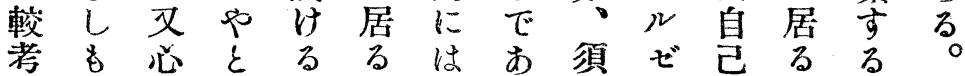

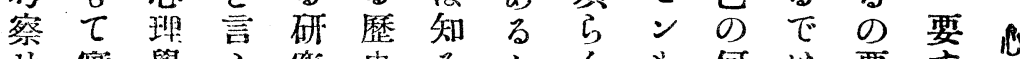
ば驗に學々等史る

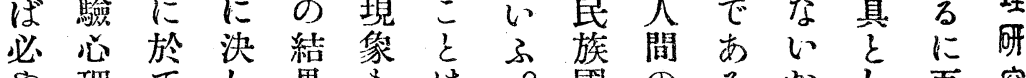
二队理 $\tau し$ 果 8 は 國のるかし吾究 、理學 \& $\tau$ 或计合民本か。等

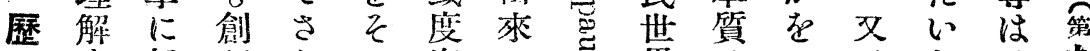

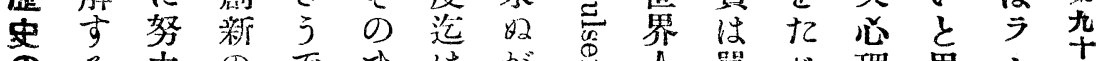

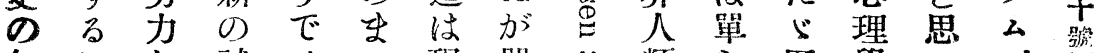

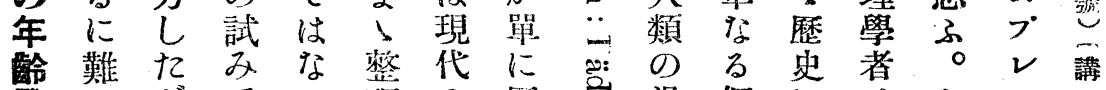

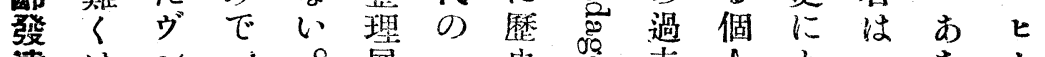

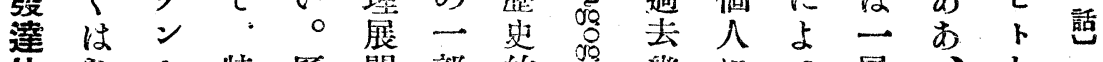

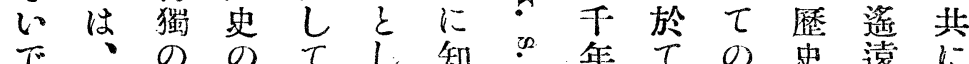

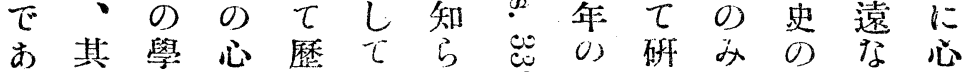

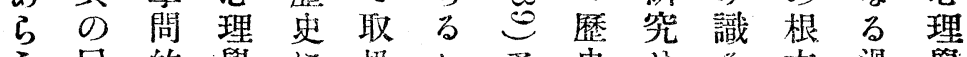

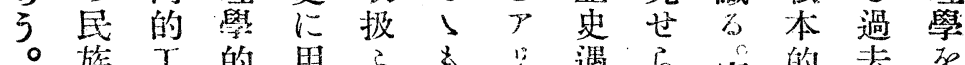

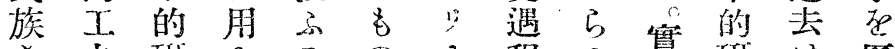

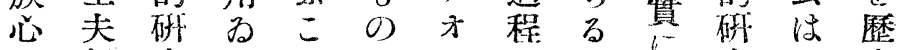

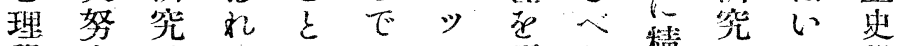

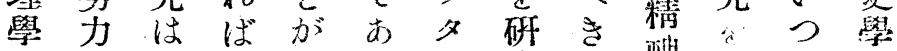

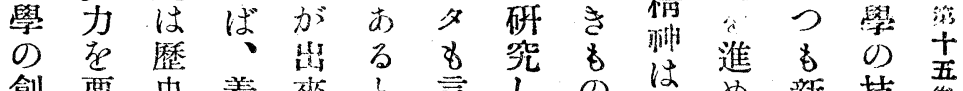

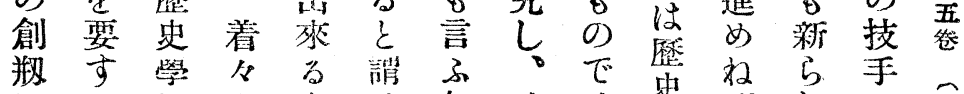

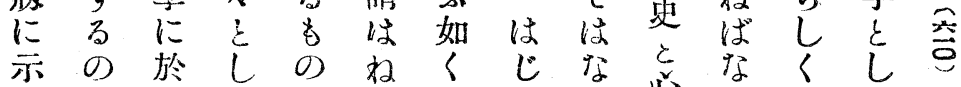

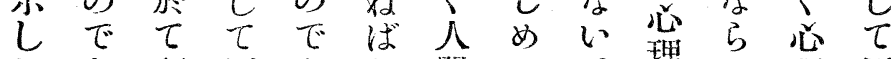

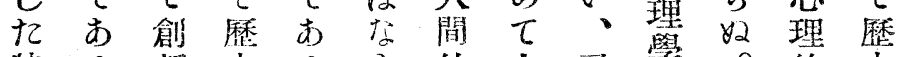
特了新史るら的人又學。的史 獨。

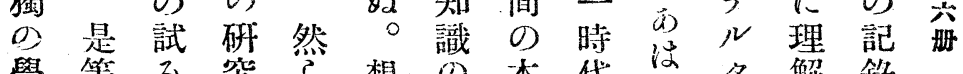

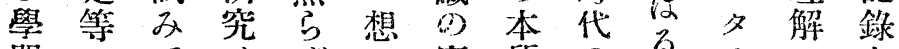

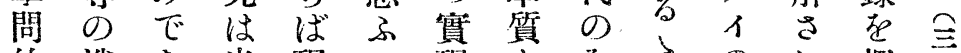

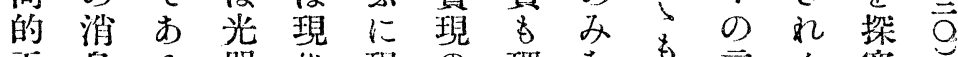

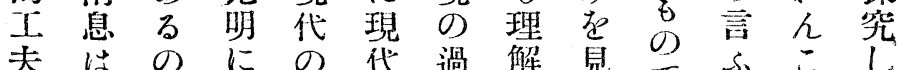
夫崩のにの代過解自宁心こし 努鎑及照心

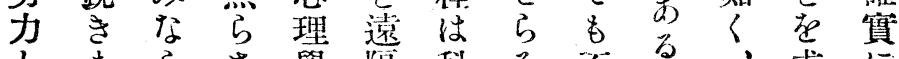

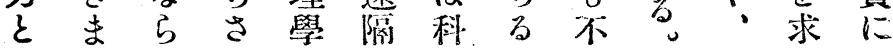


求にき化 の の化做頃春西とバ識

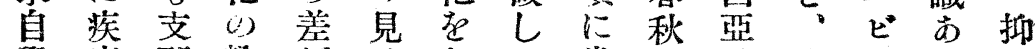

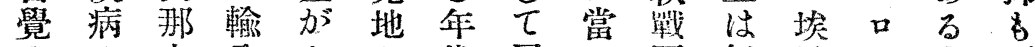
0ゃ交入市上代居る國紀及二人歷 歷勃

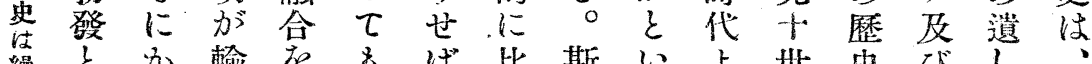

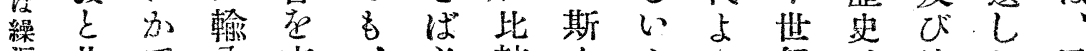
难共で入來: 必較く及紀ほ埃䎲民

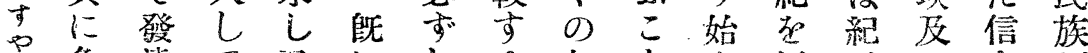

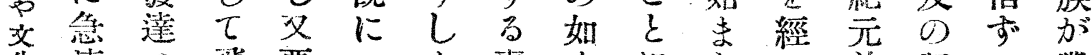

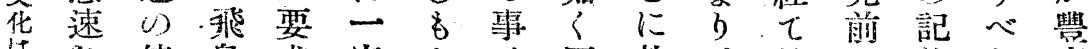
渄广停鳥求定さ织歷就、始至錄き富 步る灌時ののう一史き日乎で記に 發し代增登で見發て本う年市録し

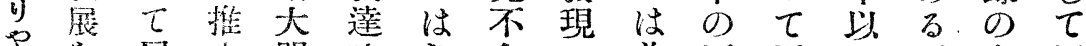
居汸開時な合の普歷居上。存活

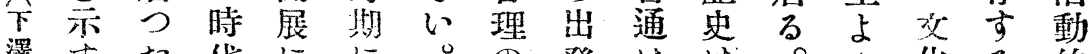

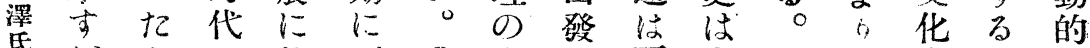

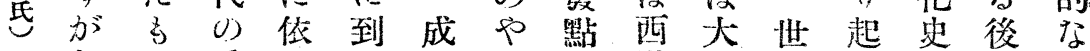

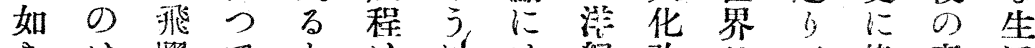

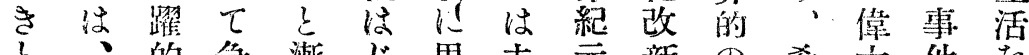

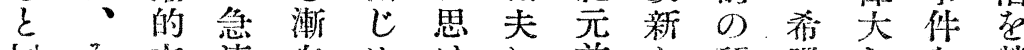

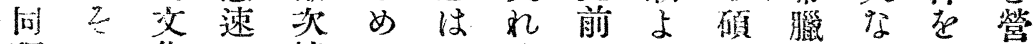
理 9 化 で障るる近幾、〈世始白紀貢凹や あ害生發乙百否非紀采鳥元献る 万

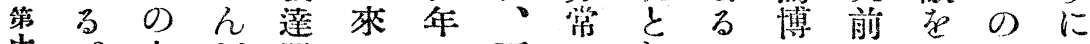
直去だ開るの不なと主分なでな

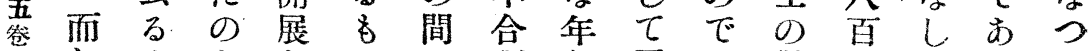

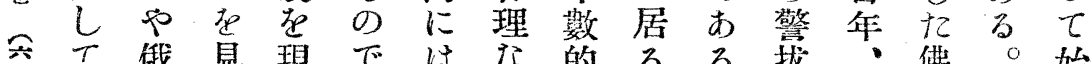
突厂俄見現ではな的るる拔、佛。始

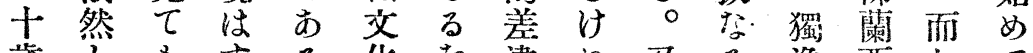

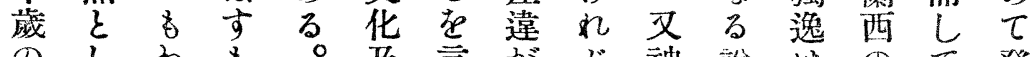
のしわ方居言が神誰性のて發 等 $\tau$ の 即 びふあ或武に紀セ精現 筫兒身るでち歷人る學天從元二確害

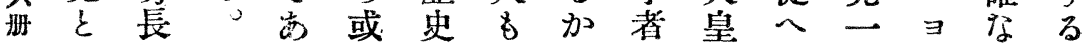

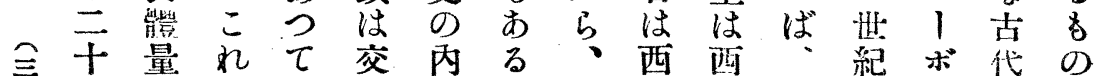

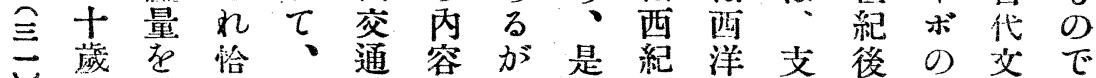

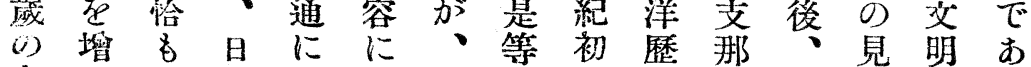
青し青本依於然の年史の而解のつ 年, 年につ热歷頃の歷しに記て

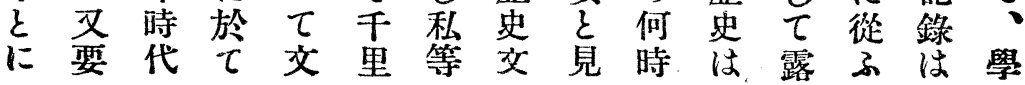




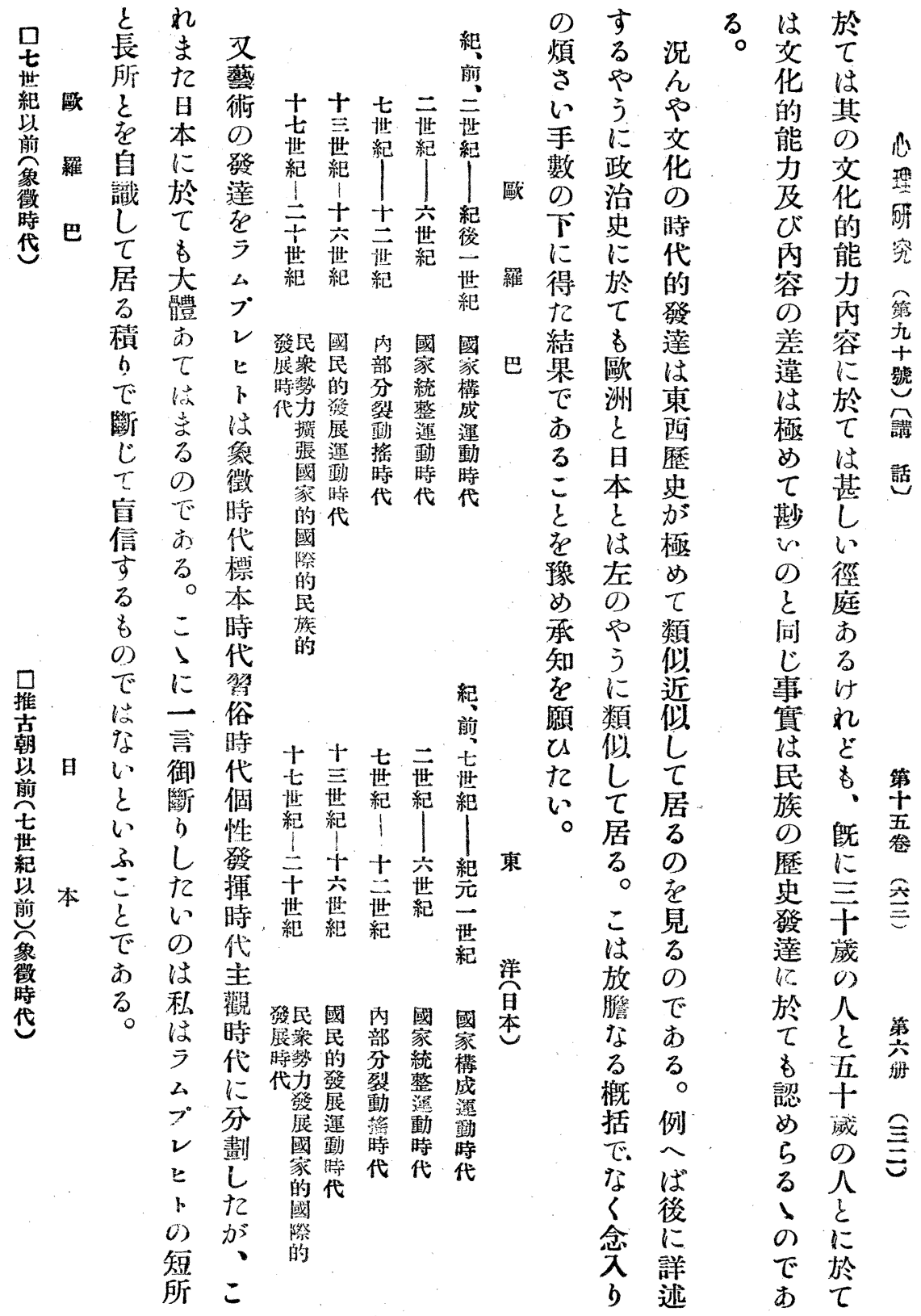



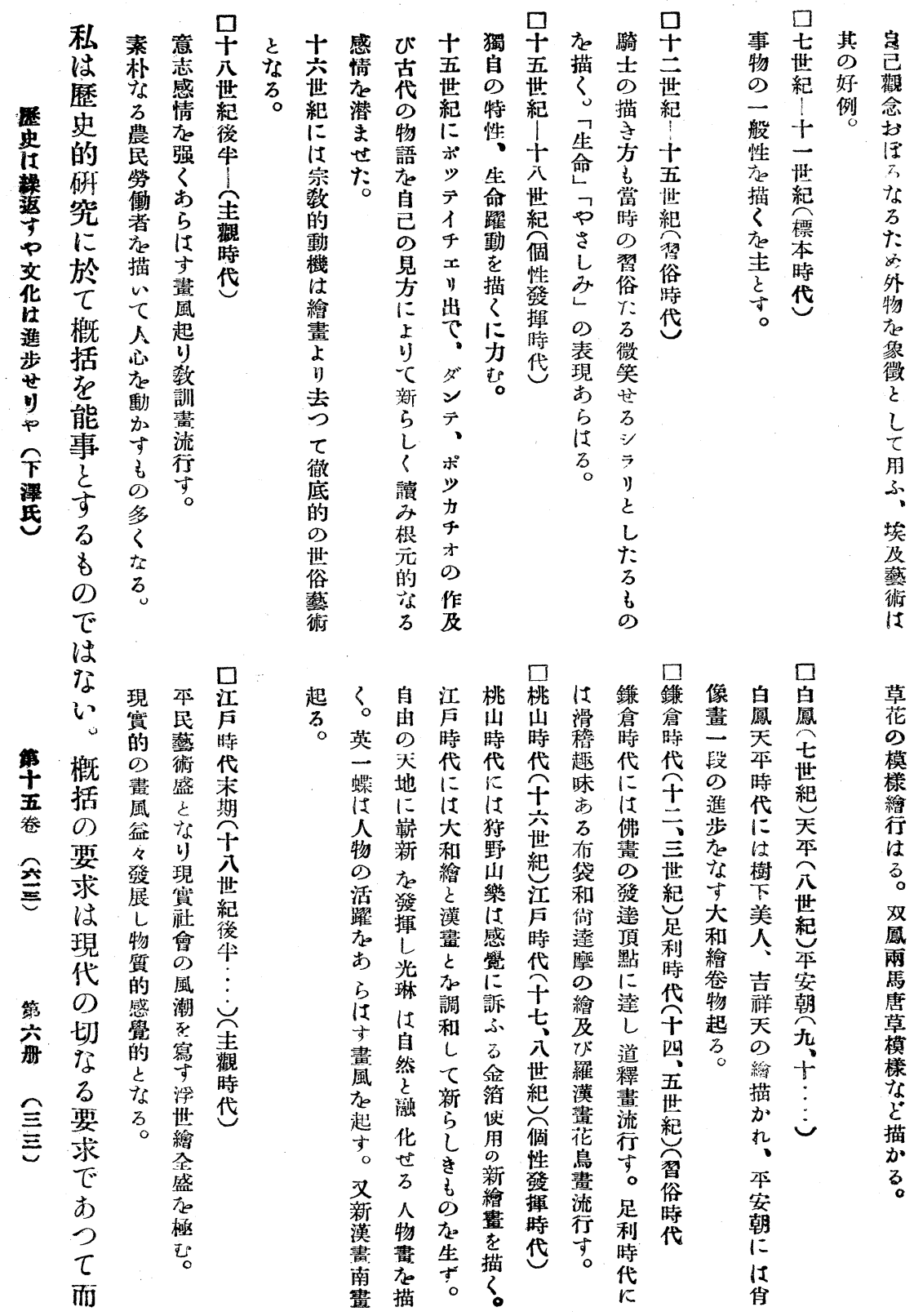


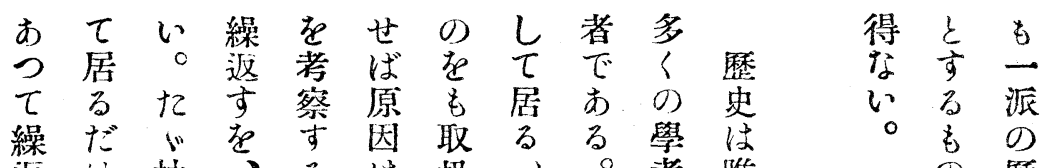
返け抽、るは扱、。者唯

すの象自時存ふ歷自の而

でこ的然は在。史然中回

なとな科歷せ自湈犁に的

心で自學史风然真學も個

$\varepsilon 、$ 然 $\varepsilon$ 的 $\varepsilon$ 然 $\varepsilon 、$ 別

心又科同見に歷個歷昂的

肉學樣地な史人史然の

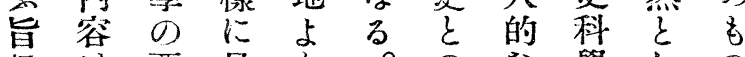

趣は要見b贯しのの

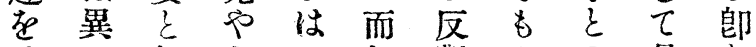

述るしう二L對の是

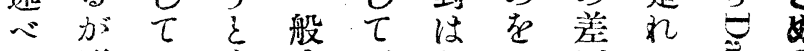

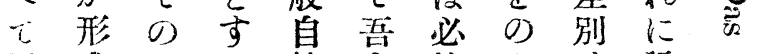

居式みる然人然みは說

る表同誤的は文取單き

繰じ取個自扱に文

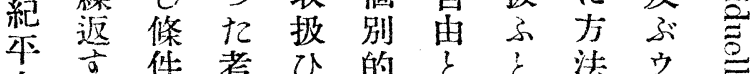

交高件考

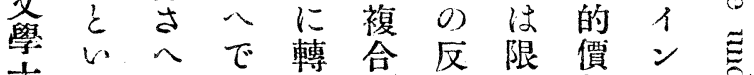

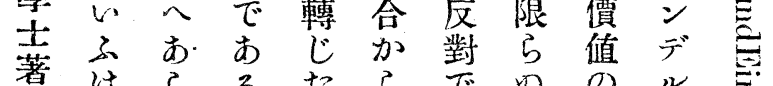

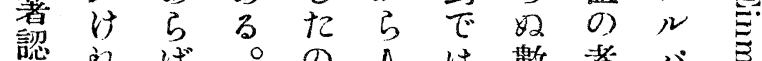

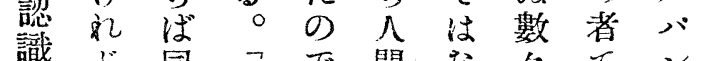

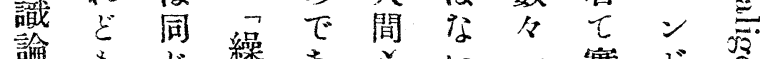

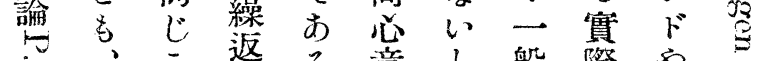

形等意般祭や

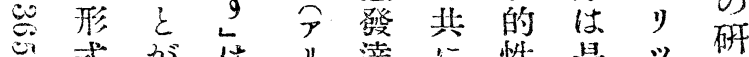

式起は如少達歷啠等尔究

巳に起㚾学の 歷質等 ケ等

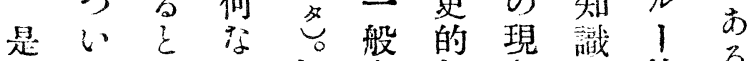

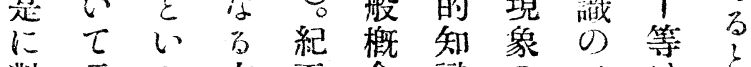

對言了方本念識の三戦

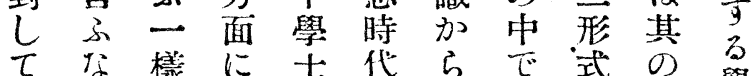

て

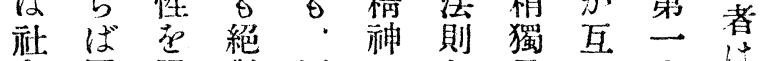

會同限對歷の息に人多 學一定に史發除な混之多

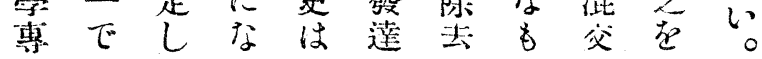

の 歷

で史

あ 家

るの、即

三 0 欲究

絽而 せ

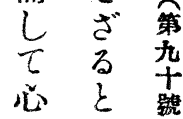

學亏篦

と で

歷方話

史 あ

學 ら

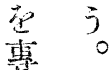

攻 吾

字

るは

私、た

の ங்

音精䓪

$\varepsilon$ 铳

ᄂ 研

究类

當 共

然に

こ概 籍

に的 册

至 研

る 究要

き併

没進

已素 
過頻てたん闰認し現な

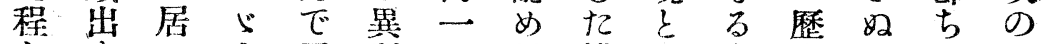

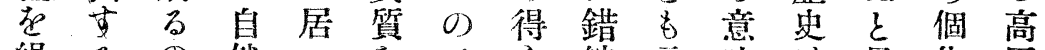

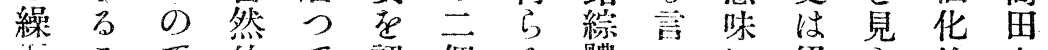

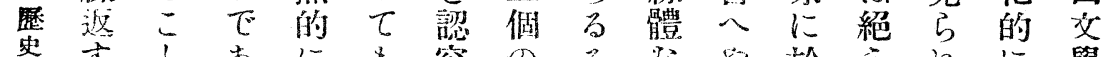

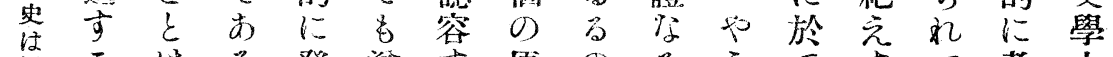

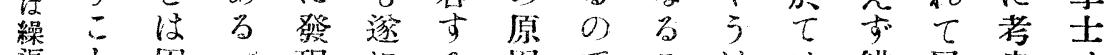

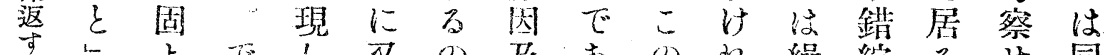
す

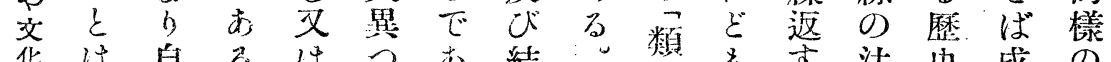
华息るはつ尚結。型型高法史成の 進意然か消代る果例型、と 則現程問 步義 $ら ら$ 減形。は人民私いに俩一題 せ㤎數自しで事ばいは支と切に

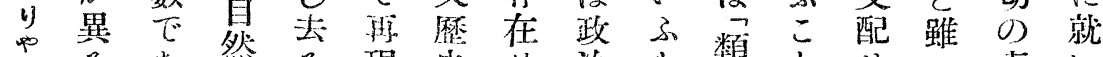

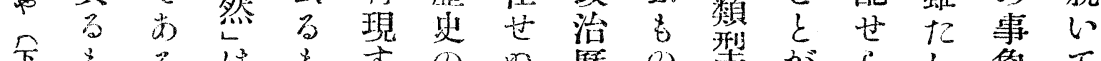

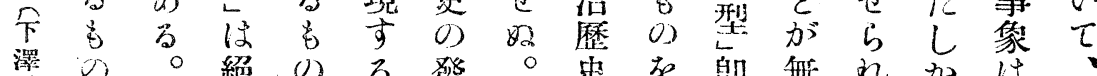

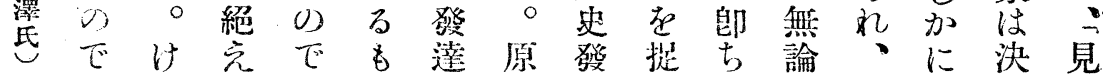

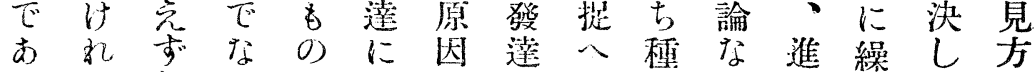

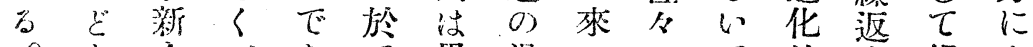

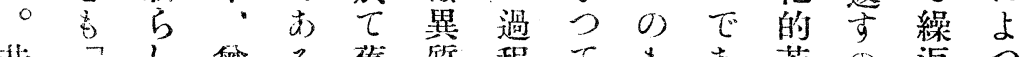

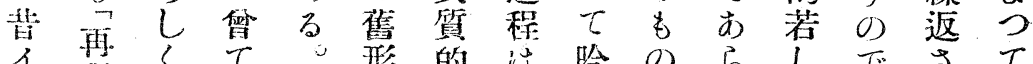

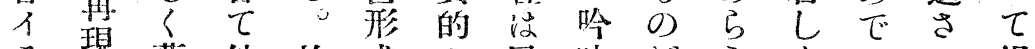

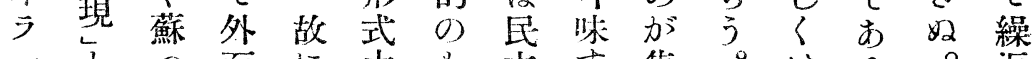

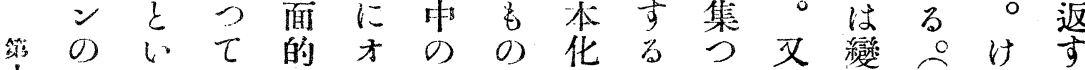
苪? 吾ズこく越ケ質あ君所居式的田

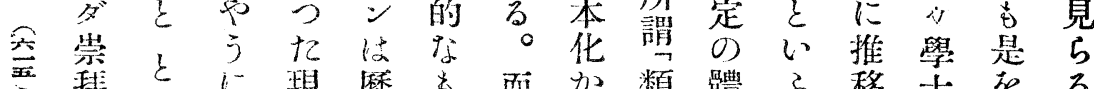

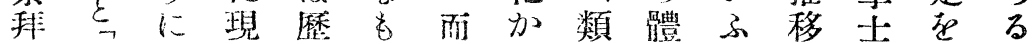
者一歴乐史のしに型系熟し著普り

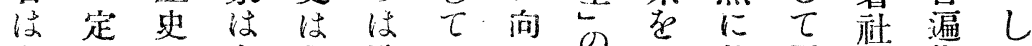

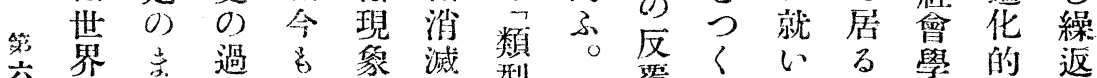

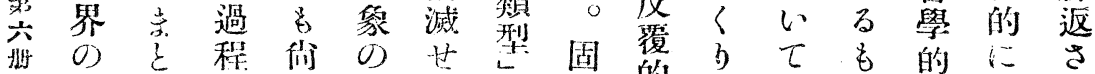

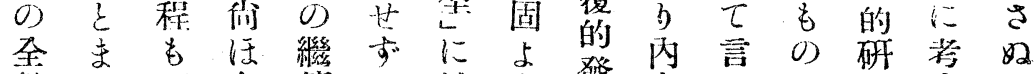

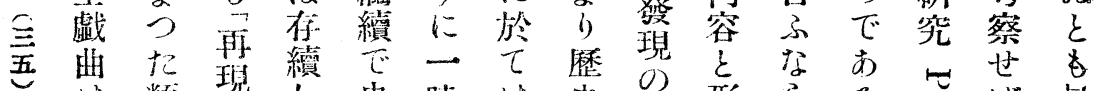

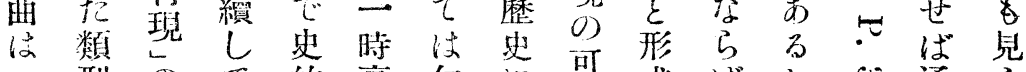
一型のて的裹甮に能式ばか心通ら

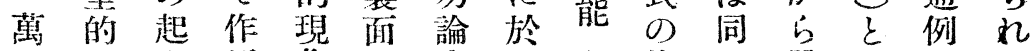

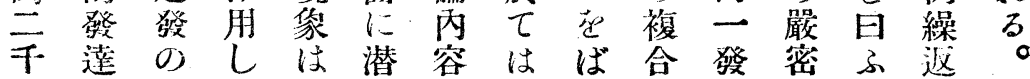


はつ性具個る

合 $\tau$ 體性。人

法す合的艺郎交

性比罟 事

の䡆志㑰る 歷像

类的点加史

の少视ら例に複

者數导抽へ於雜

認事䒯ばてな

め實を綜封取る

るを有合建报部

9 論しし制了分

だ理てた度個や

あ 的 居 概、性 過

る要る念宗は程

而求存篮共單多

し下通革の

てに悋の、統の

法普ば條民一集

則遍な件族に合

(化らと精 依 の

し 基神 己

离 た 畏的時成

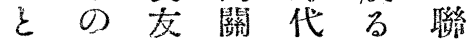

心に城係精 個 絡

了過厅を神性で

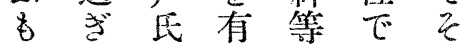

のなの李なはは

は心言る告考一

こでふす究く種

の歷如の是、特

合史?で等多別

法現嚴あ情樣な

性象密る—關

の尔。種統係

或中意隨 の二の

るに味つ類に型

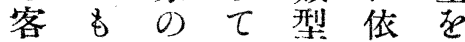

觀 或 合是的 つ造

化程 法 等 價

意度性は做生守て

味でい法念る居
寧 $て ら の$ 過史 内

万を過程わに

將絶し程を過演

來六放進程了

の夺の認め老求

問創で西て吟る

題造ある居味々理 た的る气当市し叺

四市に加光にるた究 る-ら方過に方

歴々 類 、出ぎ其こ第 象言型こ來明 心 の卆

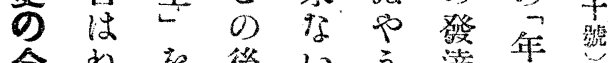

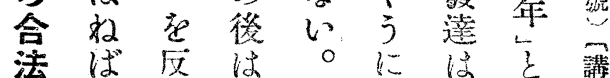
性尔覆或け見采京話

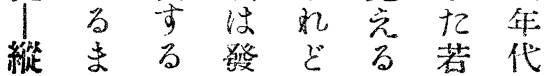
の 歴。過過今鬼し意 史芯程やに<踏 まに世角潮で 心所界、進市 ○謂快こ的る 要繰 1 视發加 寸莑人迄達号

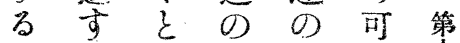
に元過畺成五 繰現 万程最䉥 返萣ま他遥 云垷它於に迢突 名心はつ年 $の$ 加 $\tau$ 嚴 $\tau$ 數 問 世密 僅 題知界な 岕表筫 はれ史意に示伪 世的味五记 界が に六て 歷・大於位居言 史而回元のる に簙同發。 於元期一澾世 $\tau$ 水区單界 蛙子市覆位歷 
别 $て$

の攻こ 社

哲いはの史又果む體す 砝究弇 者哲來題於 史 0 加動 允存學 を學少はて 界こらかの 歷を進力者 何め説 夕

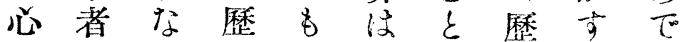
理はい史妥普を史心古 學この的當遍概現引る

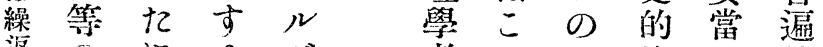

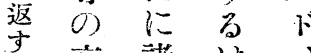
苏楛讨ド 交涉國机 シ 吾。 帒のの 準な 法导ル

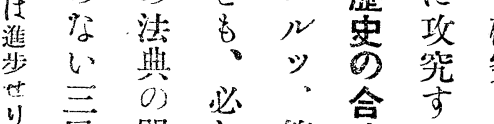

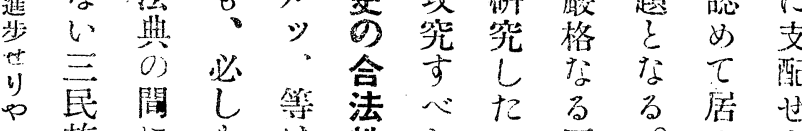

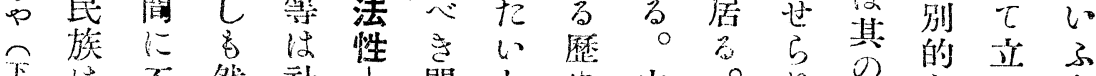

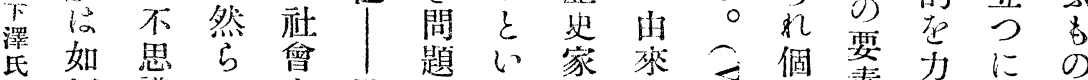

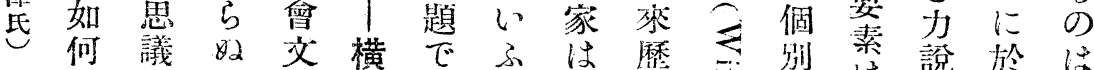

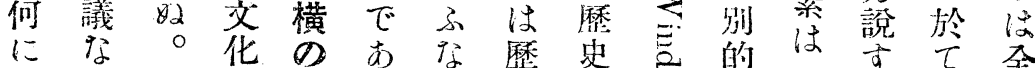

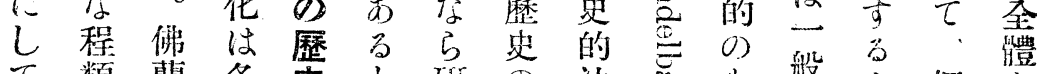

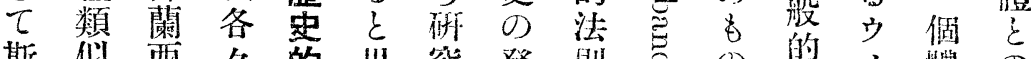

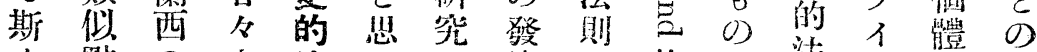

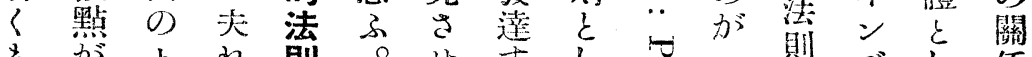

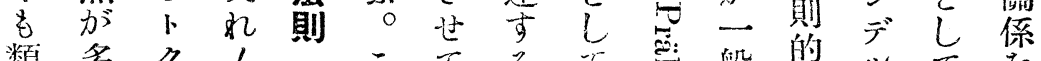

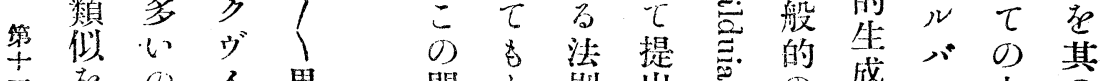

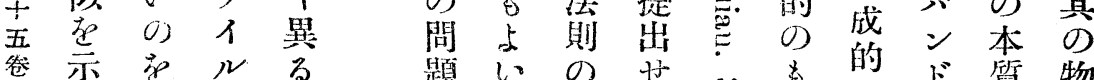

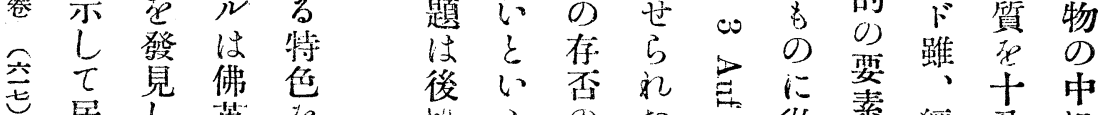

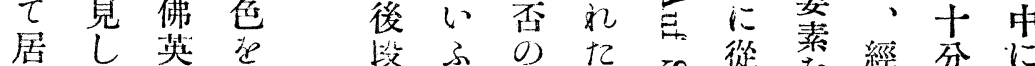

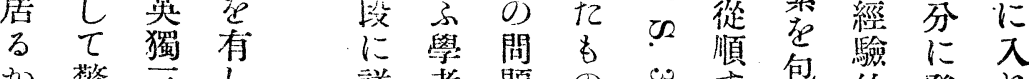

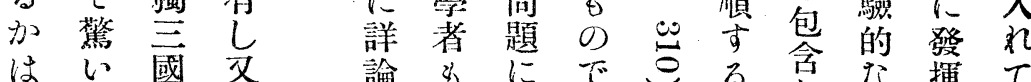
第はい國㝊論々にでのる含な揮て

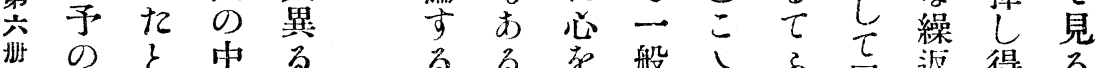

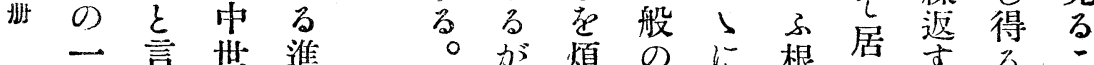

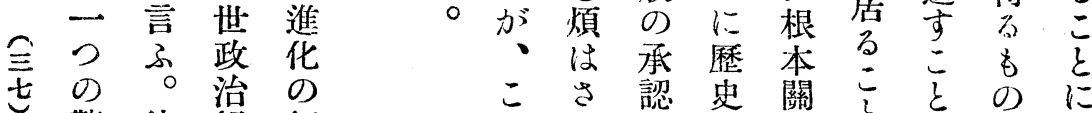
蕉彼組 徑 異は織 路 で個にを あ々 就 有 万、別认，守

こ認史關岂方手に は叹をは係忌のだ依 歷で得繰は学出あつ

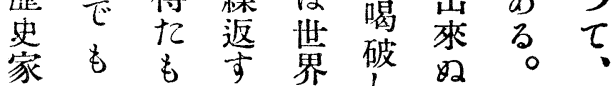

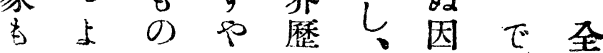


歷な

$\begin{array}{lll}\text { 史 } & b & 7 \\ \varepsilon & \varepsilon & v\end{array}$

( あ) 1

及 加

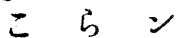

そさぬ は

にま其

はにの

政言荠

治牲占

r

い早

了本 方

こ た

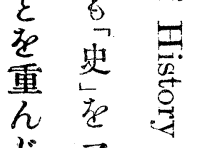

艺

居》

居当芭

成々於

程 讀 $\tau$

歷 歷

史、史

は或は

是は過

步去

政歴の

治史 政

更過學

交 のだ

史 政 治

に治學

大

別 ᄂ 現

寸在

る 言の

こ证歷
外に民て 外せい登類想を

來歐を開界や。達型へ言

物西 ᄀ展のう餎階の代つ

子 大 $\vec{L}$ 刺 $\varepsilon$ 論段史敢て

心共御 $\tau$ 激亦文上實 $\tau$ 居心

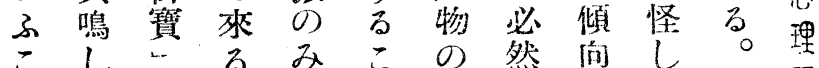

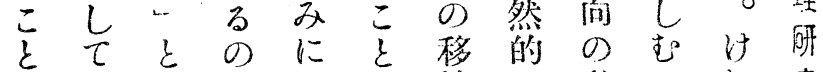

六に民古で由怔植に發にれ究

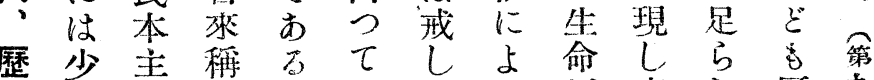

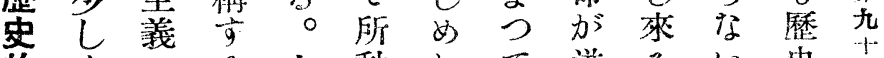
的くのる夫動㱛て 迸.万心史號 發語絶日可的ば生ばこで と先

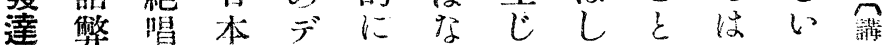

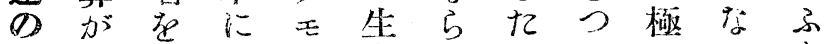
時あ生は》香风のうめいる 話 間るん上 單。代古シま近多現多。は の中1の時名し き吾同 だ世ので我あり在らじ 际思は國るて見注く 會通想江に來元東飲 比它く於机了、西み 意 $\tau$ 如内 $\tau \ddot{~}$

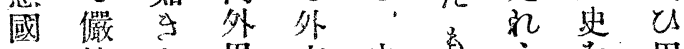
民然界來史定永思第

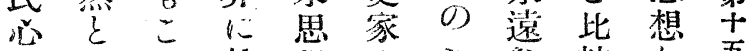
意し洁想のな染較し忢 の $\tau$ 元 $て$ 往るる 攻行

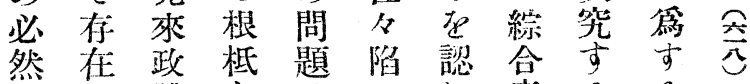
的し體走はる意るる 發、有や如る志に人 薘要直しか人に方晁間 は求接相ま監躊發西の第 々の 關 互しら躇展時行輁 こ高係に心に卡代動

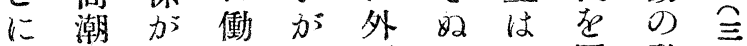

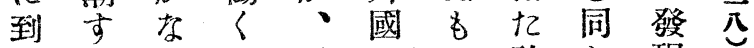
達るいこ元のの椊じ現

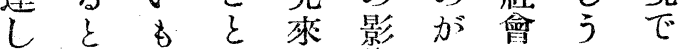
たこのに認響尠心し のろで依識にく意元る

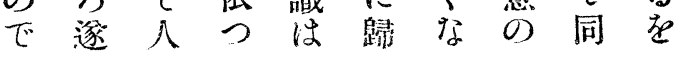




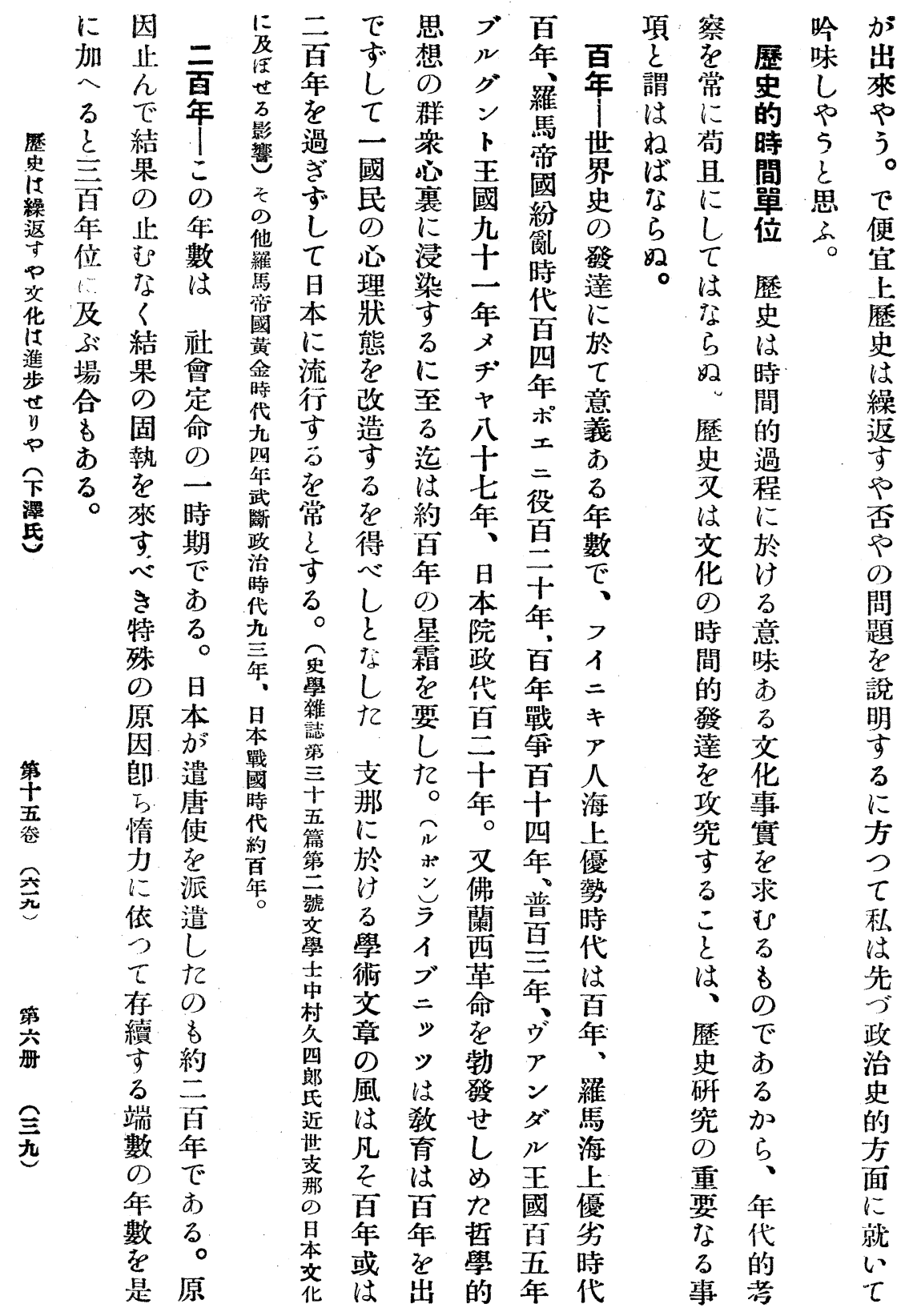


年一者 興

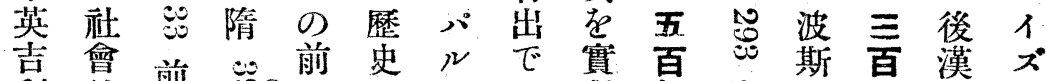

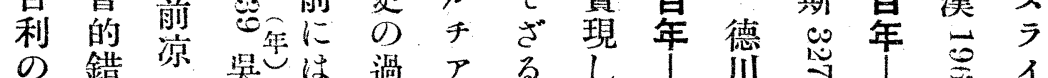

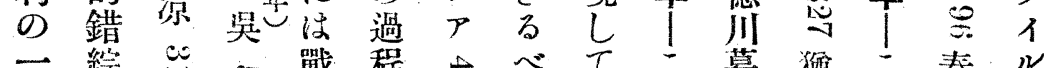

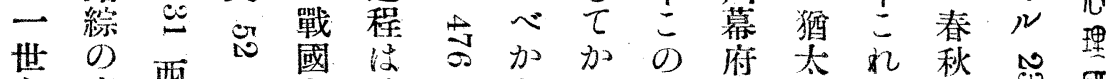

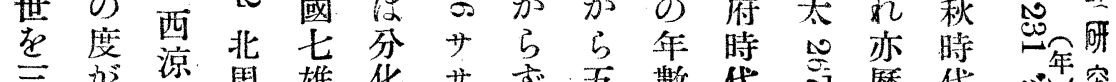

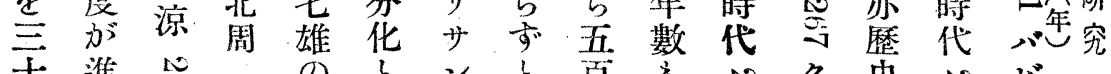
主進

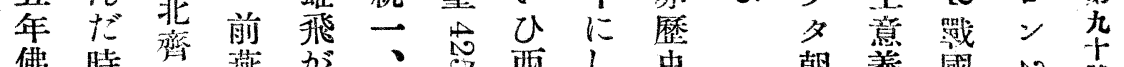
佛時弯燕苾、怘西し史

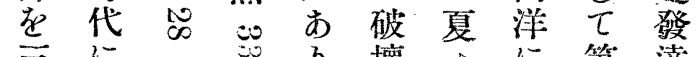

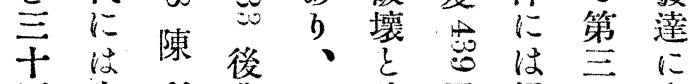
四牛恕燕少建羅媂灭意

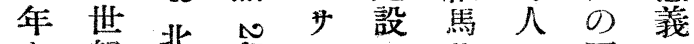

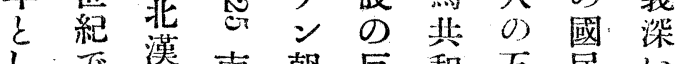
し、飞溪南朝反和五民心 、轉气燕の復時百的年 七盂前㟔起飞代年自數

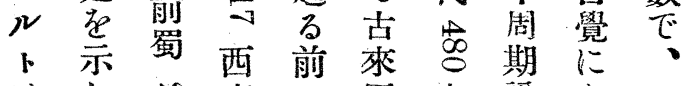
はし品秦结歴帝說上旦

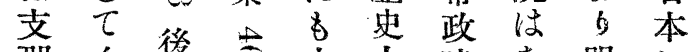
郱々㿻志尔贞時市明点

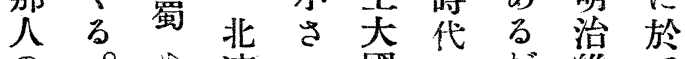
の。凉的國出加維 $\tau$

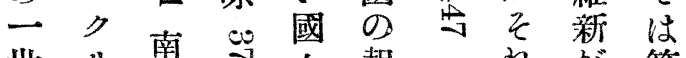
世”南品起名第

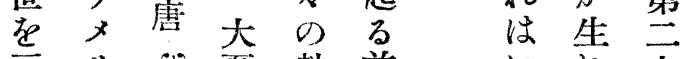
y哭夏勃前沙灭 干加扛

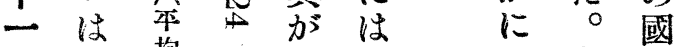

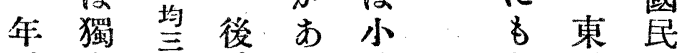

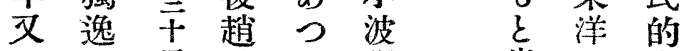

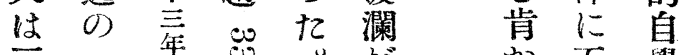
三露路觉

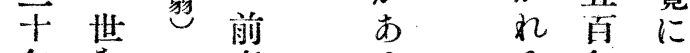
年卷秦石

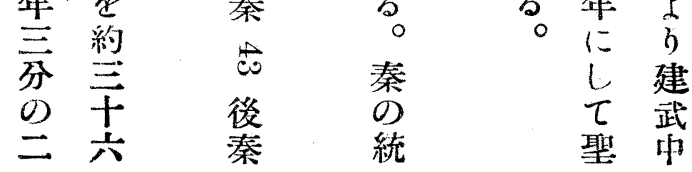
朝義國芯裙

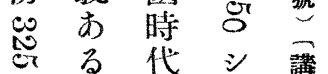
策年 $\vec{b}$ 品 數 $\vec{\circ}$ 广話 筑羅 唐市篤点 品方王 新 政 希 工國時㨫 今名代 学孝若 王竞同 國年獨夕算 繁戴 录䒧 西等治些

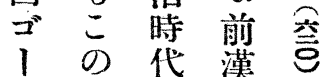

例总 苔 摆心潮

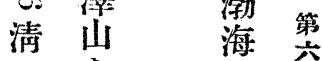
总弯苔等 埃。英四

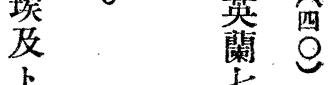

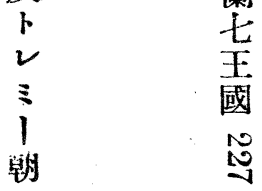




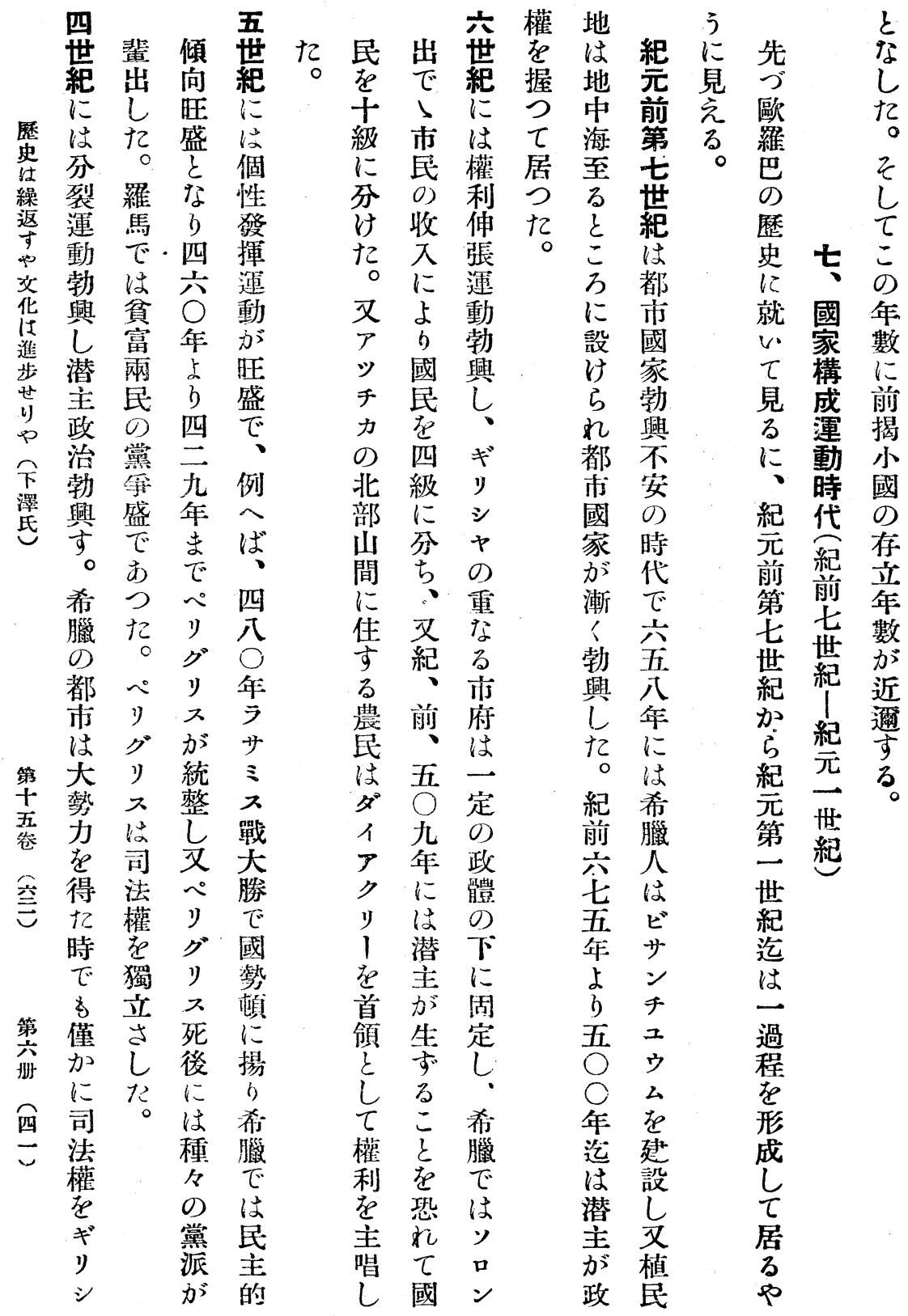




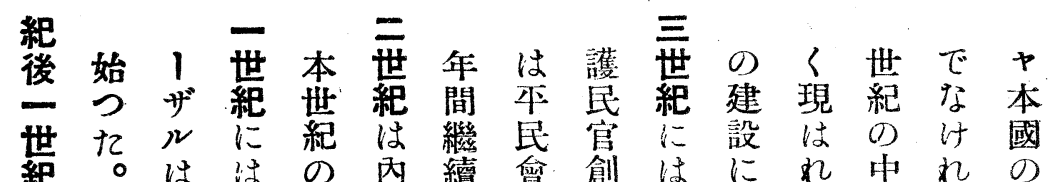
終帝 前部し議設本努、葉ば大心 大身權半紛れ方せ民力個にな部理 帝 ヂがに㑷市起ら階し人頂らに研

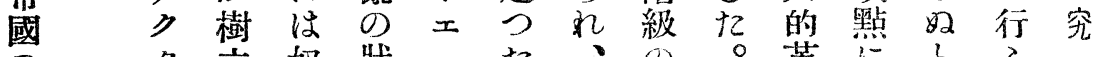

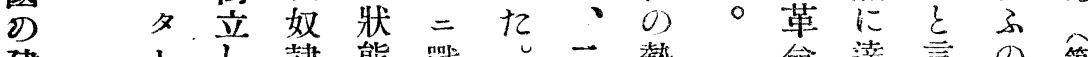

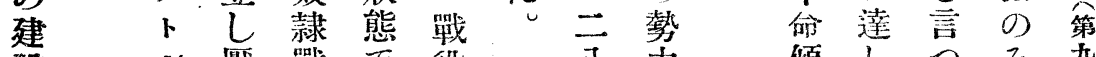

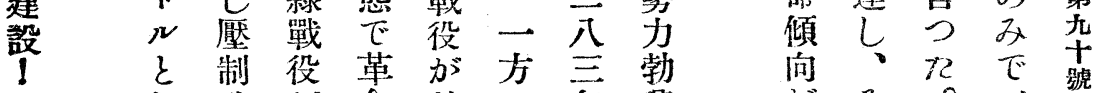

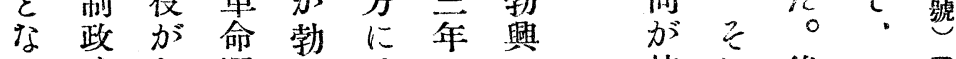

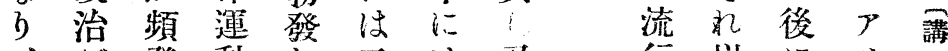

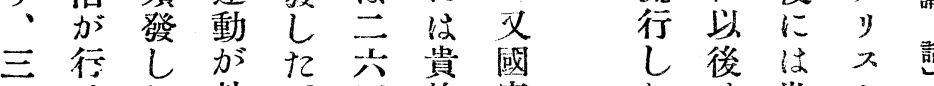
○恃住勃。四族家 年れ。興年本は に片江民外 は。襍は的 $\curlyvee$ 郎篤其發 ウち郎虾に展 グ社 ち 发同存 ス會 一邦じな \%國焉热裁し

又家吾援制仿

加的

政 集

權 中

を運

握 動 年家管

视怡世 。市界 が民國 レ 、加家 1 三國實 严家現 四に0 希 年 對，試 臘 アするに レるが於第 $\eta$ 感現计等 专情梳方䙲 $>$ 视國 5 稱 制

媔染言受皆

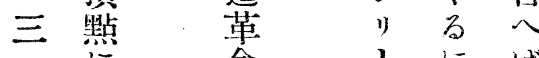

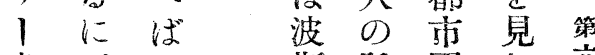
年选遥島至等

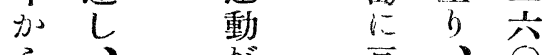

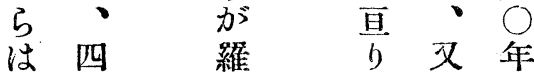

厭四

馬遂本に

制 年

红

政 に

治は

起

?

に世は

百 紀 羅

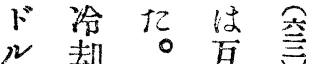

大し即に

王個 ち 顏

は人都存

斯孤國知弈

に立家

遠的の得四

征利希方兰

乙己臘國

世傾艾家

界向明 の

邦方积

國漸本度 


\section{三 芯}

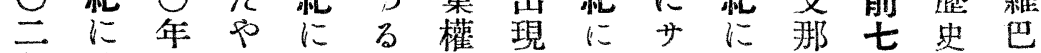

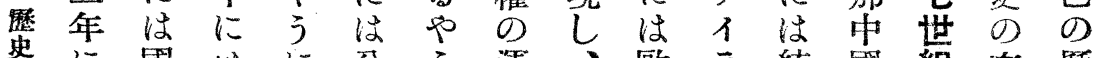
丳に國はに分引連、歐亏統國紀奈歷 繰 家張諸裂に動弱羅 ス に法何吏 渠漢的儀方運な在肉巴王運は外品

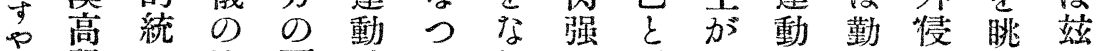
齐租二連覇勃 华遇衡者起。、のじら旺主國や一

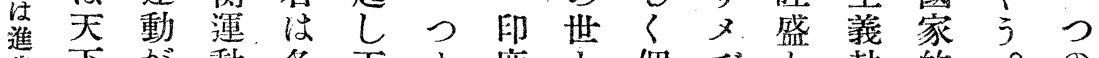
步下 加動 各天ま度

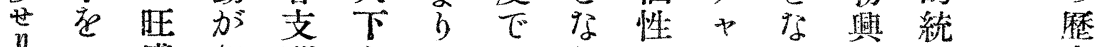

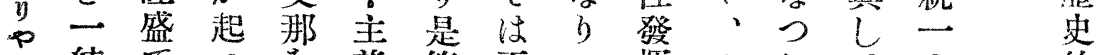
令統でつ を戔等五一揮りた、の 的

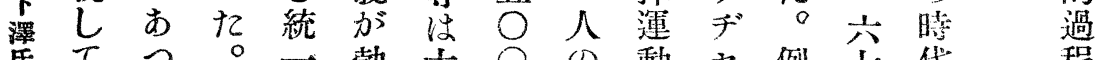
氏

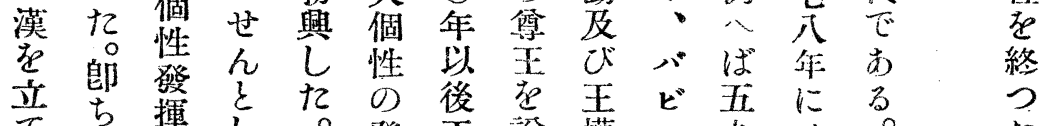
て ち 揮し た。

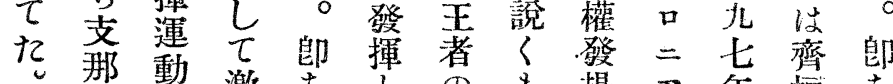

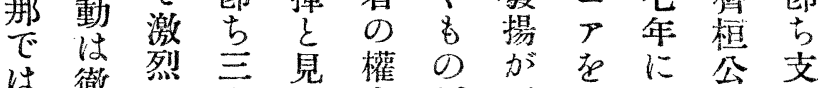
第秦底に六做力加旺征は籊 贲始し活门し著な盛服楚逐だ 吾皇元動年得し心菜し莊に心

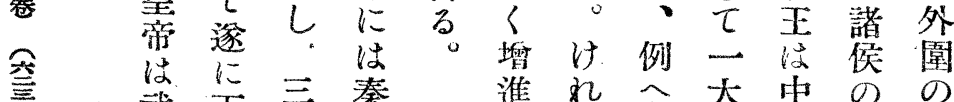

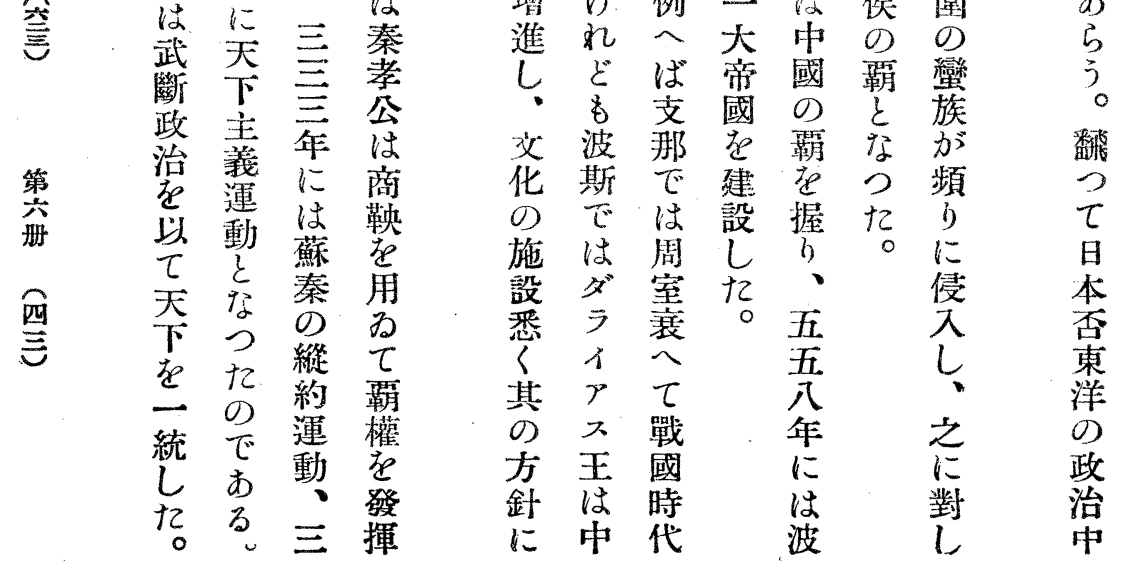




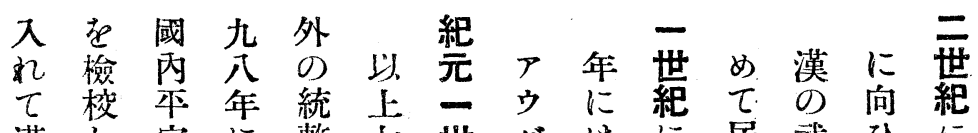
漢し定に整七世グはに居武ひに に紳紀は老世紀 ス四はる。帝、は心 服社綱羅寛䋧國

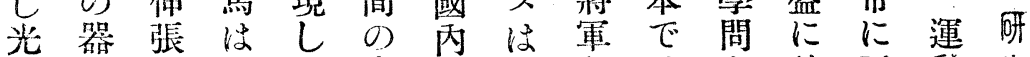

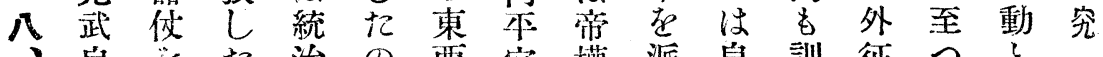
國皇蒂收 の 家よめで墸あ治綱掌し發の。頂征卆

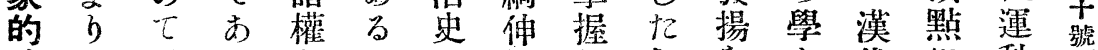

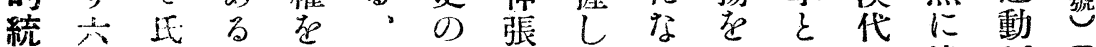
整十族。君見過!て手なに達が霖 運年の郎主占程世纪しっ於し旺

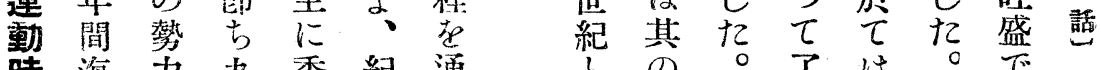

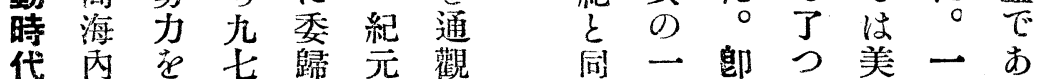

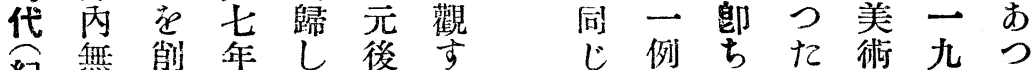
紀事心に、第る なで呙の迄九

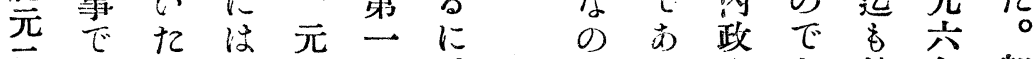
世漢。日 老世:は潮 世室支本院紀相興。〈る。に 紀 棼帮武はに對味是整。的匈支

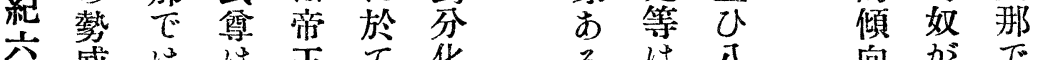

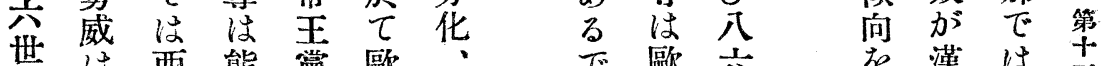

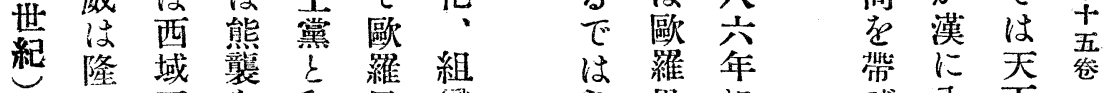
夕五虞和巴織 之十年衰汇統 し 餘定協は一 $\tau$ 國し動 羅、 居裏・し馬擴 万海 又元張 れの景國帝等

。演行事國 江天心過 至皇當建程 るは設を 迄諸、也經 悉神旦ら元 くの本礼逐 質神でたに な斿入下

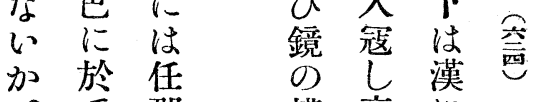
模 高に ヶ 耘樣䔃 1 保每 ザ護 球是せ管

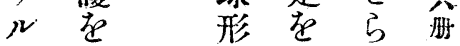
が旦在親初 $\boldsymbol{\prime}^{\circ}$ 本輪征 $\tau$ 四 yに形し 年四 $>$ 乞 $\therefore \tau$ 的 老重敗藏 征、列证 分公 せ 統 


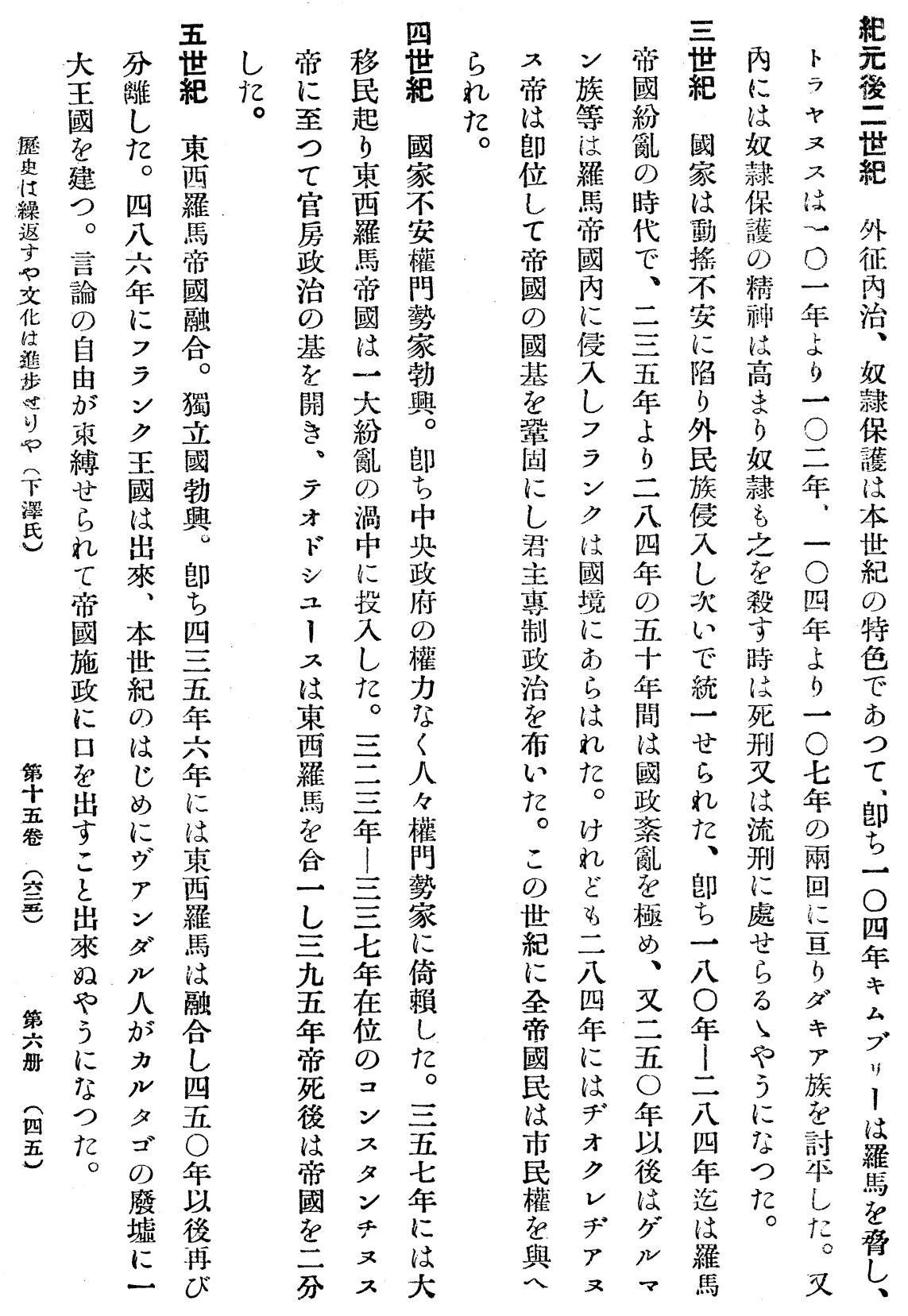


九世紀大世煘紀元で見本が利見 1 世 年紀の臣紀は後はるあ勢にるプ紀

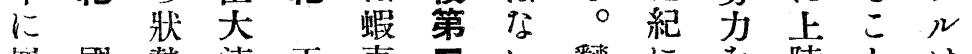

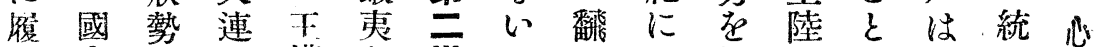

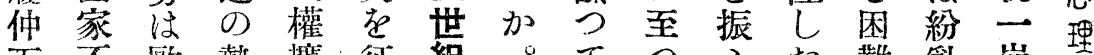

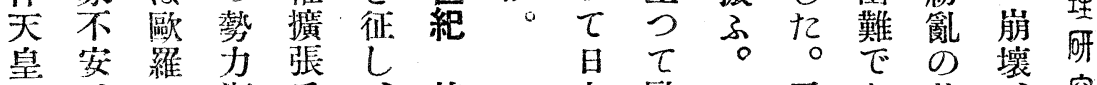
田潮氐: 族本歐又基究

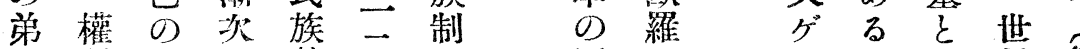
任門同加勢三政歷巴第界

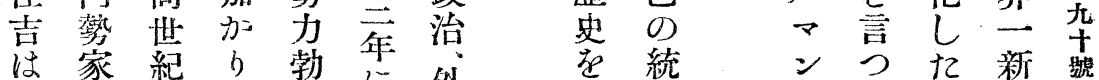

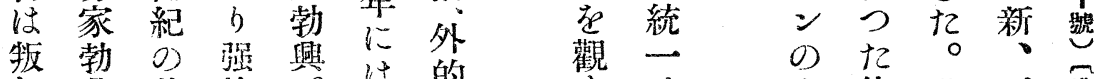

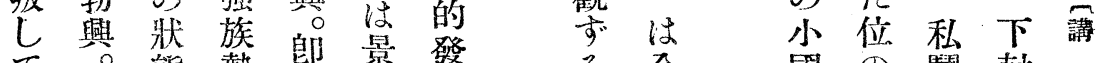
$\tau$ ○ 態 勢 勘景擘

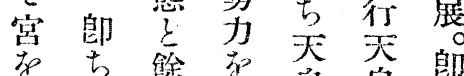

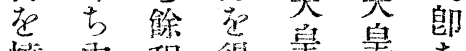
琵丙程得王東 き部類爽朵國三

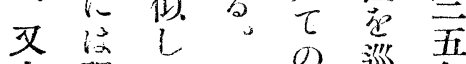

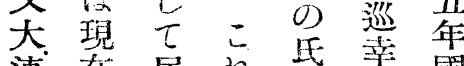
連在居机范等國 大 の るは亲 す 臣製。國卒朝

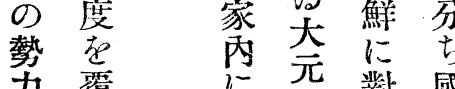
盆覆不完對國

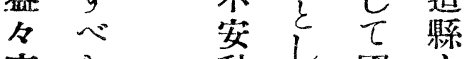
高き動元國王

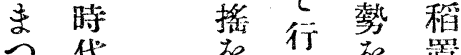

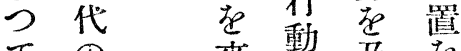

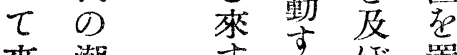
桃潮高、挋置

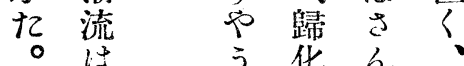

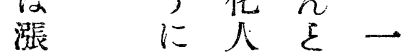
与漱尼一

爽子く要 0

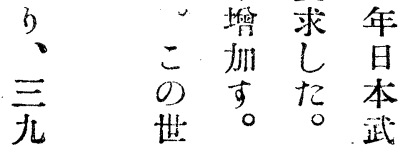

总全

矢 崩

張 壤 略 ᄂ 3 世 歐 界 維蛙

巴 -

と 新

同

橉

o) 0

過 玄

程 に

箱

進 史

み蛙

$\tau$ 第

第 巻

次

の 過

過 程

程 灰

尼終

終 号

万 t

$\tau$ 如
國の闘越

家狀混尘

は態鯍 精 起にの神 与陷世個 $\therefore$ 蛋人 宮、開禁 宰外展力 は去し勃 王 り ギ 興 尖蛙求。 与變二郎第

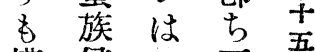
權侵こ五崉 力又的四

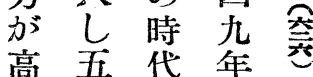
高当貸 \%五上五 记年罪琵箠 $\bar{y}$ ㄹ 才者岳四 Fy赑突 $\bar{r}$ 下 等 万人

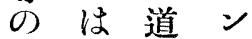
女伊德

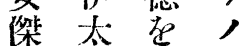




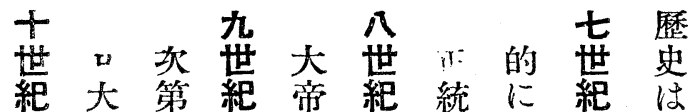

歷民帝点統在外室宰封進紀統屬國

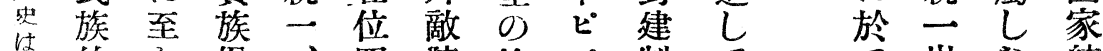
繰的 马膤・四防 餘ビ制て統

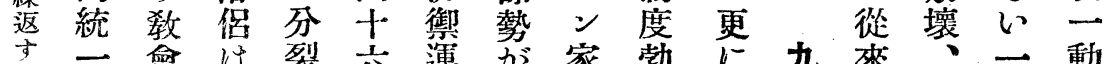
吉一會 化封或立王間。汪屬。弓内共人別。 法建家 ○權に郎强し古し 部產思大郎

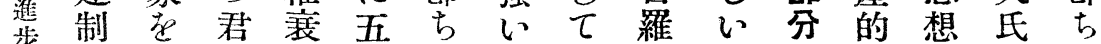
世度結主退十異。封馬過裂社勃

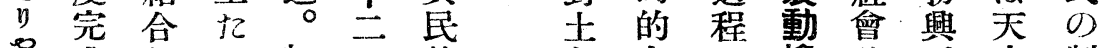

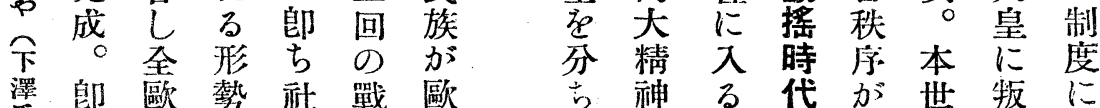

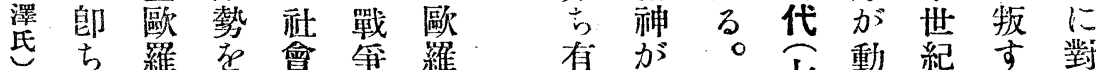

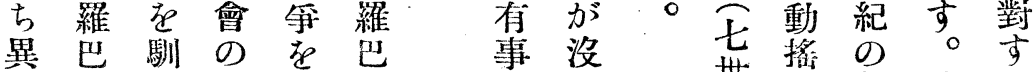

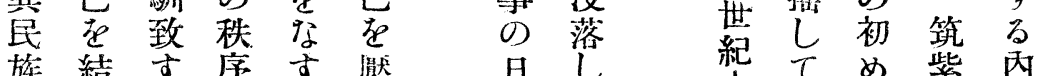

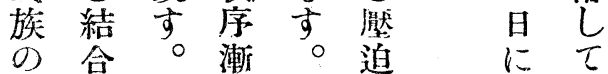

排含本々宮 L 忠大 压元世整章节 傕其紀 Us

第. 動 の よ 君ピセ

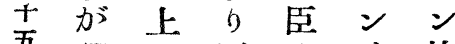
恶起元王の施

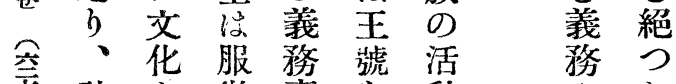

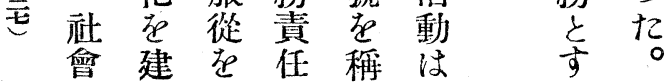
の設要加产歐方六 秩世求規万維分

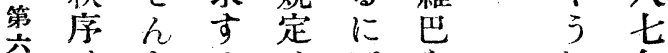

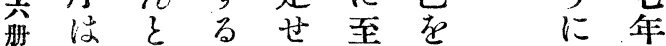
整し實ら弓威少大

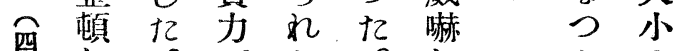

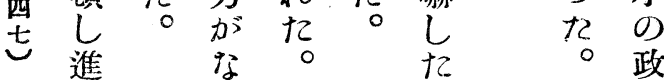

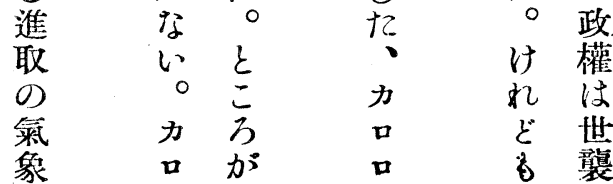
士來武等 三记烈盤 世。开動 紀皇は掏 量新蛙 時羅 遂 - $k$ 天通外 皇じ部 民 $\tau に$ 万謀 古 丙 叛 5

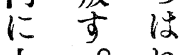
大。水 梦化 動 督 播 天 部皇 起合 多時 又 天 
天 壳眽

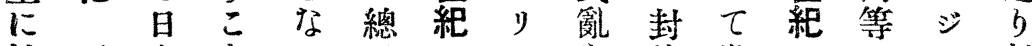

抗王本々 る

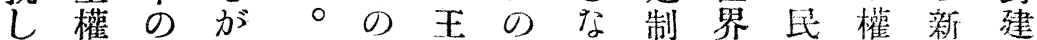

自動 經 行 佛諸 權 諸古度統族利組炐理

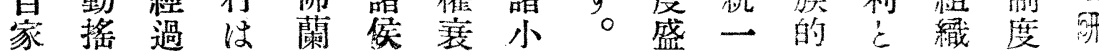
の國党和西加退國都にの反賽成方究 權粹自てに集、穴府行大動力る完

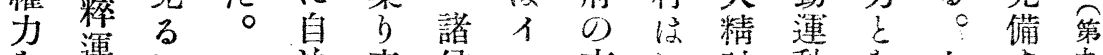

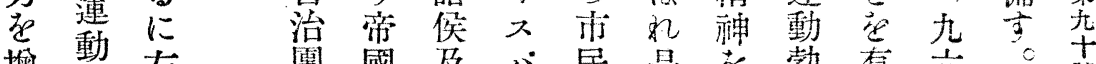

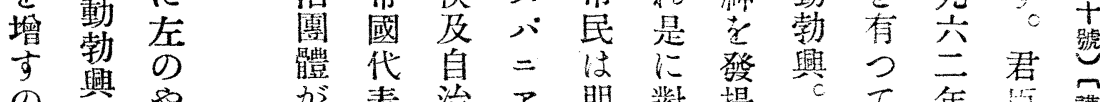

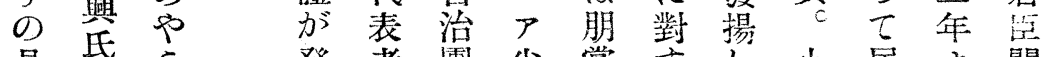
具族 5 發者 團牛黨 方し小居才關 講

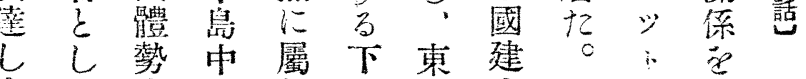
委度

の 興

が 的

起 ち b 保

聖 流

自七力走し民維草丙！結 治行勃部七の馬不的大心゙ 團動興以爭不帝本元菅公

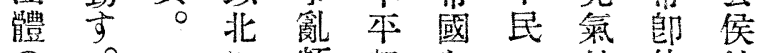
の 0 -に頻起责一外位伯

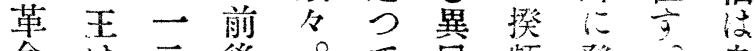
命は二後。只层頻發”自 方最三し又諸族叠し佛ら 興早年て广汅の澜王

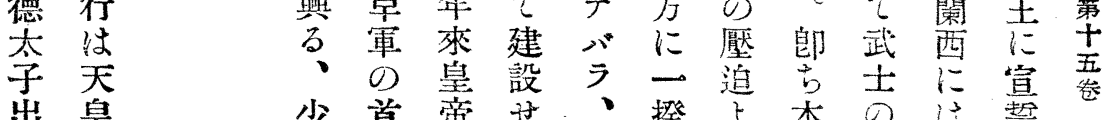
出 皇 だの

】權

皇力

權当

の 弱

復く

興 ᄂ

ま 後

計代

b 12

亏佛

之 较

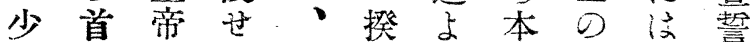

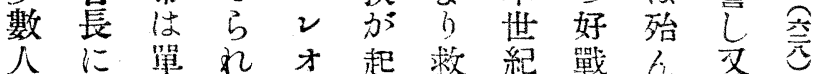

士

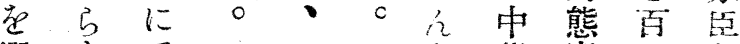

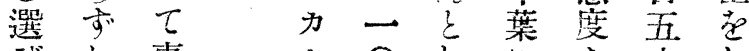

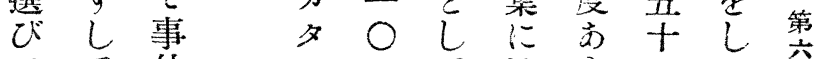

$\tau \tau$ 件 二 $\tau$ 法

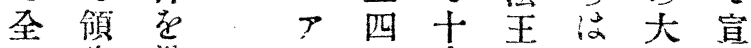

八内遂、年学攵に主譬四

民 の 行 ア カ 秩 寸

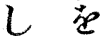

代序る

表 の 力

ゴブ爭り过市め

不立

者支加

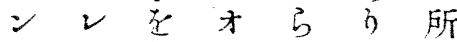

- 1 起长名何㟪

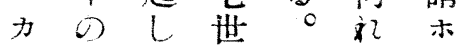




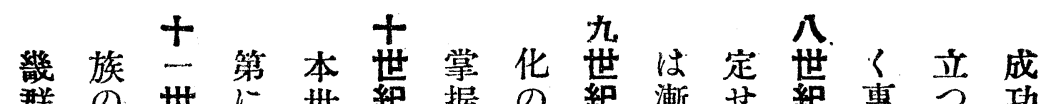

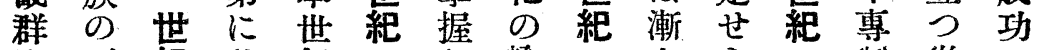

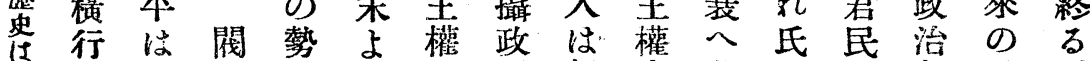

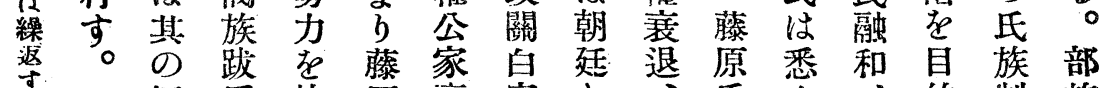

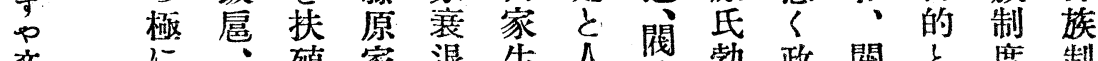
齐に: 殖家退生人族勃閂々度制

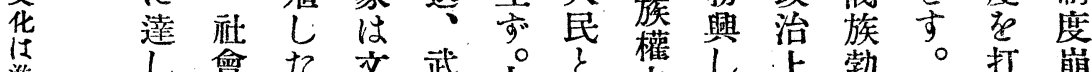

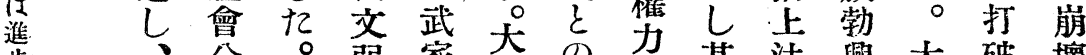
步。弱芜花品芿其洼興大破壞

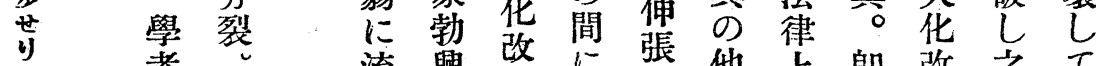

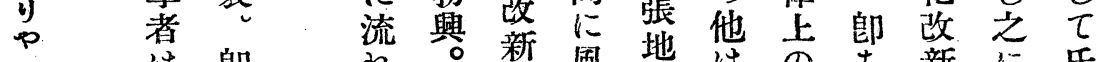

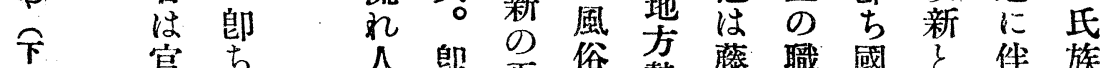

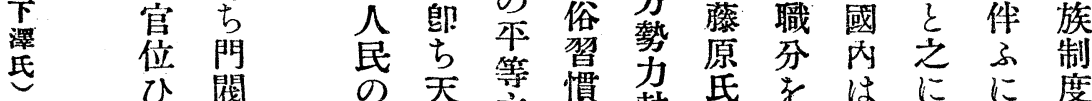
ひ閂 の天等慣妿氏皁はにに度

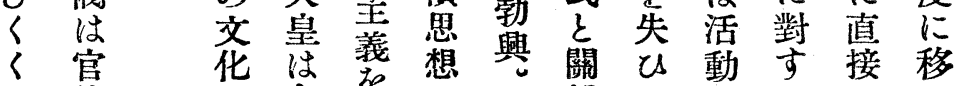

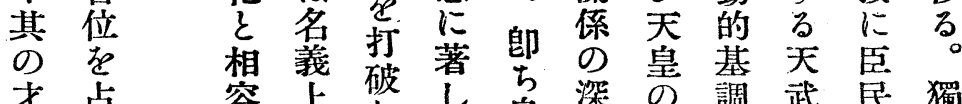
才占容吉破し 5 澡皇調武民獨

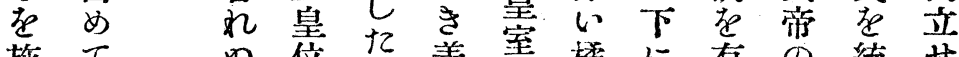

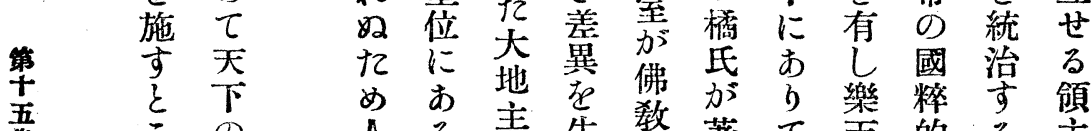

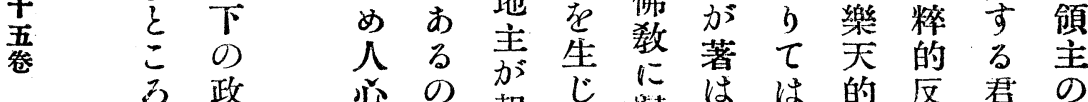

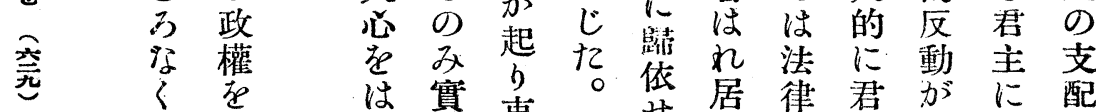

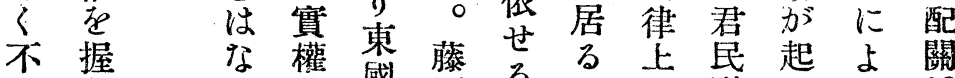

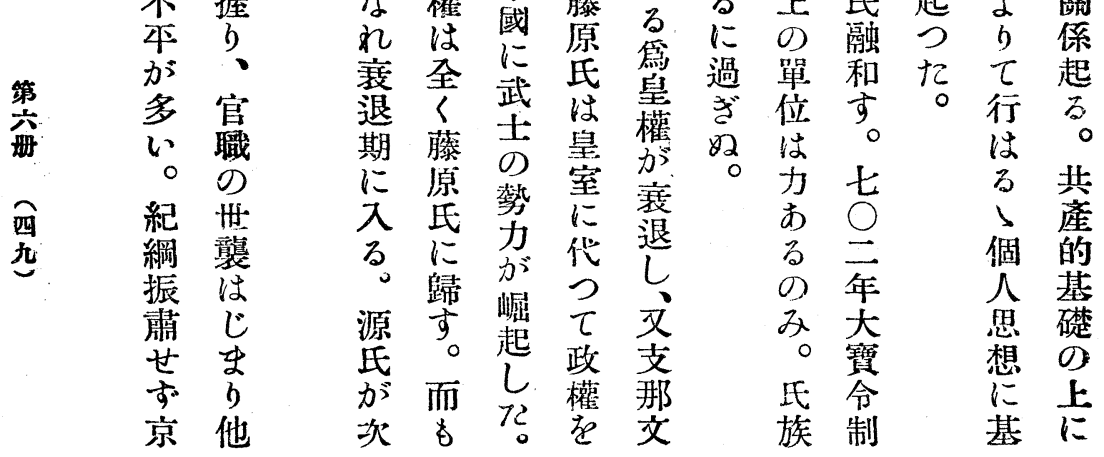




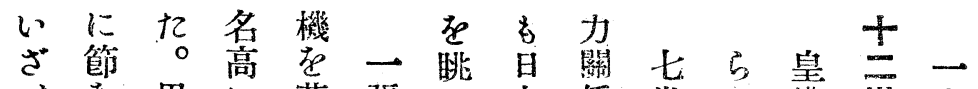

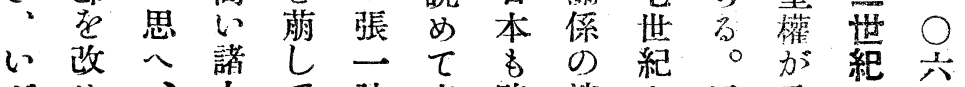

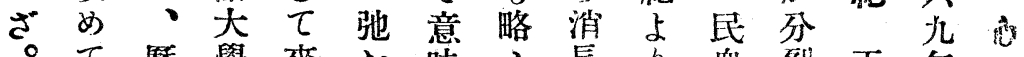

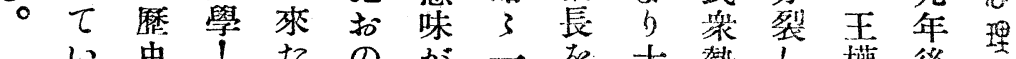

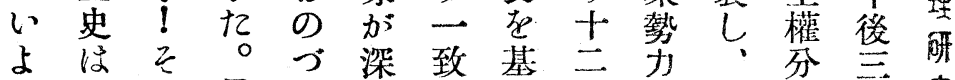

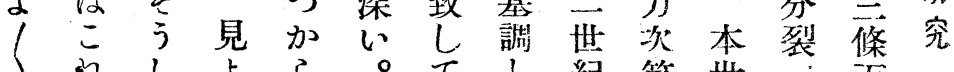

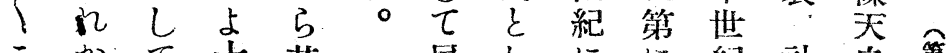
こかて 加其㷴しにに紀社皇第

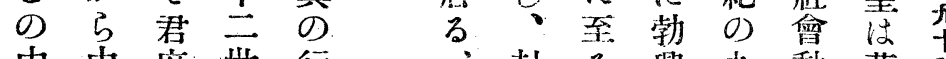
中中府世行、封 3 興九動藤

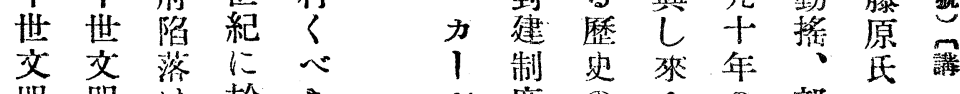

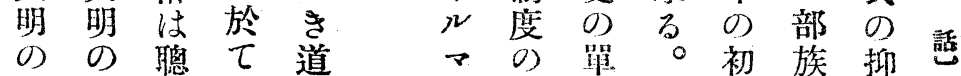

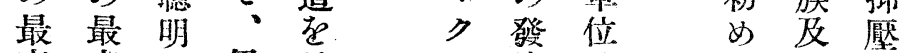
高高な伊辿 期潮理太 近期智利 $\tau$

代なのに腤 交る力恃遷 明第に和默 の十秀口移 黎 $三$ = 明世 期 紀 學大爽 に渚學て

し 躍 业英中 つ在等世 L $\tau$ L 莉齐

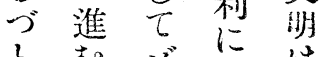

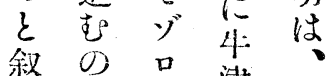

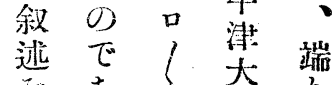
然棸學

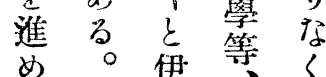
入達的 は過 管 程 $\tau$ 民

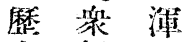
史努一 被为的 階 手江 級勃 樋 戰 興 觀 拿红 の至后 歷了に 网㨦 飞移王

あ被 当特龊 色閥 發衣族 見泉及 乞态建告

周与悡法

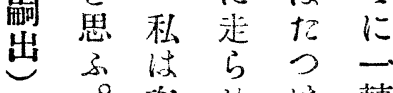
L 3 U

扛二部 加族 乙蛙宠

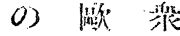

時羅 9

代巴嵥

に d to

終民筑

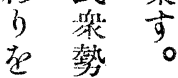

告力

〈”。勃 哜

地 郎

结

武藤

人 原

勃 民

興 0

ᄂ 政

中所

央 政

權 治

力

战
照

被

地 變

方

勢

策

力 院

政

制告 